Cornell Law Library

Scholarship@Cornell Law: A Digital Repository

Cornell Law Faculty Publications

Faculty Scholarship

Spring 2007

\title{
Neutral Citation, Court Web Sites, and Access to Authoritative Case Law
}

Peter W. Martin

Cornell Law School, peter.martin@cornell.edu

Follow this and additional works at: http://scholarship.law.cornell.edu/facpub

Part of the Computer Law Commons, Law and Society Commons, and the Legal Writing and Research Commons

\section{Recommended Citation}

Martin, Peter W., "Neutral Citation, Court Web Sites, and Access to Authoritative Case Law" (2007). Cornell Law Faculty Publications. Paper 1178.

http://scholarship.law.cornell.edu/facpub/1178

This Article is brought to you for free and open access by the Faculty Scholarship at Scholarship@Cornell Law: A Digital Repository. It has been accepted for inclusion in Cornell Law Faculty Publications by an authorized administrator of Scholarship@Cornell Law: A Digital Repository. For more information, please contact jmp8@cornell.edu. 


\title{
Neutral Citation, Court Web Sites, and Access to Authoritative Case Law*
}

\author{
Peter W. Martin**
}

\begin{abstract}
In 1994, the Wisconsin Bar and the Wisconsin Judicial Council together urged the state's supreme court to take two dramatic steps with the combined aim of improving access to state case law: adopt a new system of neutral format citation and establish a digital archive of decisions directly available to all publishers and the public. The recommendations set off a firestorm, and the court deferred decision on the package. In the dozen or so years since those events, the background conditions have shifted dramatically. Neutral format citation has been endorsed by AALL and the ABA and formally adopted in a number of states, including Wisconsin. Thomson's acquisition of the West Publishing Company in 1996 removed the principal source of opposition. Court Web sites, nonexistent in 1994, are now a standard feature of e-government with the result that the idea of a public case archive, open to all, no longer stretches imaginations. With the environment seemingly so much more hospitable to the 1994 Wisconsin recommendations, one might expect to see them widely implemented. Yet less than a handful of states have effectively put them to work in tandem. Professor Martin explores some of the reasons why they stand today as lonely illustrations of "best practice."
\end{abstract}

\section{Introduction}

\section{Wisconsin Report and the Reaction}

I1 In June 1994, the Board of Governors of the Wisconsin Bar, embracing a report prepared by its Technology Resource Committee, recommended that the Wisconsin Supreme Court adopt a new system of "vendor neutral" and

* (C) Peter W. Martin, 2007. This work is licensed under the Creative Commons Attribution-Noncommer cial-ShareAlike 2.5 License. To view a copy of this license, visit http://creativecommons.org/licenses/ by-nc-sa/2.5/ or send a letter to Creative Commons, 543 Howard St., 5th Floor, San Francisco, CA, 94105, USA. This article is an edited version of remarks delivered at Legal Information and the Development of American Law: Further Thinking about the Thoughts of Bob Berring, a symposium held at Boalt Hall on the University of California, Berkeley campus, Oct. 21, 2006.

** Jane M.G. Foster Professor of Law, Cornell Law School, Ithaca, New York, and cofounder, Legal Information Institute.

1. Vendor neutrality was subsequently explained by the Citation Formats Committee of the American Association of Law Libraries (AALL) as follows:

A vendor-neutral citation contains no proprietary data elements and makes no reference to a proprietary publication. Thus the reporter citation 100 F.2d 200, 201 is not vendor-neutral for two reasons. First, the citation directs a researcher to a West publication containing the case. Second, West has laid claim to a proprietary interest in its pinpoint pagination. By contrast, 100 Ark. 200, 201 is vendor-neutral because no proprietary claim clouds the use of any data element in the citation and because no private party owns the Arkansas Reports. The term "public domain citation" also appears in debates about citation reform. However, any difference between the terms "vendor-neutral citation" and "public domain citation" may not represent a useful distinction, since the absence of any proprietary control is the critical component of both concepts. 
"medium neutral"2 citation for state case law and establish a digital case law archive. Three months later the Wisconsin Judicial Council joined the recommendation as a cosponsor. ${ }^{3}$ As explained by the executive summary of the underlying committee report:

A "vendor neutral" and "medium neutral" citation system makes the cite depend on characteristics that are inherent in the opinions of the courts. The courts, not private publishers, determine the citation. In our proposal, citation will be to a case number and a paragraph of the opinion. The same citation will allow finding the law in printed editions, CD-Rom, via the Internet, and through new and as yet undefined technologies.

A state archive of Wisconsin case law will make opinions directly available to all publishers and to the public. The state, and not private publishers, will "own" the final text of the case law. It will encourage publishers to compete by the value that they add to opinions such as head notes or search tools, rather than by preferred access to the text of case law. ${ }^{4}$

II2 The combined aim of these proposals was to take advantage of new electronic forms of distribution to make it easier and cheaper for "lawyers and the public to obtain and use the decisions of Wisconsin courts." ${ }^{5}$ CD-ROM technology was dramatically eroding barriers to entry, and while the value of the Internet as an information channel was not then widely recognized, the committee foresaw its potential importance. ${ }^{6}$ Realizing the potential gains from direct dissemination to the public and increased private sector competition required both a new citation system and an official data source available on equal terms to all. ${ }^{7}$

II3 Those recommendations brought a storm down upon Madison. The storm was fed by a change in climactic conditions (new technology bringing fresh entrants, potential and actual, to the business of case law publishing), involved at least two clashing weather systems (the Taxpayer Assets Project

Citation Formats Comm., Am. Ass'n of Law Libraries, The Universal Legal Citation Project: A Draft User Guide to the AALL Universal Case Citation, 89 LAW LIBR. J. 7, 8, II 3 n.3 (1997), available at http://www.aallnet.org/committee/citation/case.html.

2. Vendor neutrality does not necessarily connote medium neutrality:

A medium-neutral citation consists of data elements which have intellectual or locational relevance without regard to the physical medium in which a document is fixed. By this test, the citation 100 Ark. 200, 201 is not medium-neutral, since the data elements representing the volume and page where the case is found have relevance only in a printed medium and have no natural meaning in electronic formats. Redefining cases in medium-neutral terms is possible by assigning a chronological accession number to each case. Thus the sixth opinion issued by the United States Supreme Court in 1996 can be cited in medium-neutral terms as 1996 US 6. The data elements of this citation retain their meaning in any physical format in which the case is published.

Id. at 8, II 3 n. 4 .

3. See Richard A. Leiter, Assault on the Citadel: Romancing the Crown Jewels of West Publishing, Legal. INFo. Alert, Jan. 1995, at 4.

4. Tech. Res. Comm., Wisconsin Bar, Report to the Board of Bar Governors (June 22, 1994) [hereinafter WISCONSIN BAR REPORT], available at http:/www.law.cornell.edu/papers/wiscite/wiscite overview.html.

5. Id., available at http://www.law.cornell.edu/papers/wiscite/backgrnd.html.

6. $I d$.

7. The report noted that while the two established publishers of Wisconsin law offered CD-ROM compilations, they had priced them at levels that did not threaten their print publications. Id. 
and the West Publishing Company), and was able to gather immense force moving across the Internet. Debate for and against the proposals grew heated on the LAW-LIB electronic discussion list. ${ }^{8}$ The storm's force had both enough time to concentrate and a target; the Wisconsin Supreme Court scheduled a hearing for March 21, 1995.

I44 The West Publishing Company, viewing Wisconsin as a critical front in a much broader assault on the market dominance of its comprehensive and integrated system of U.S. case reports, ${ }^{9}$ committed major resources to defeating the plan. ${ }^{10}$ West mailed an "information packet" to Wisconsin attorneys explaining the costs and hazards of the proposed scheme, sponsored a telephone survey which enabled it to report that attorneys in the state still preferred books and opposed the proposed citation scheme by a ratio of nearly two to one, ${ }^{11}$ and commissioned a study by Arthur Andersen. The study estimated that implementing the recommendations would cost Wisconsin more than $\$ 150,000$ per year. ${ }^{12}$ Last and not least, West brought Professor Bob Berring of the University of California, Berkeley School of Law, known to be skeptical about, if not opposed to, both elements of the proposal, to testify at the hearing. ${ }^{13}$ On hearing day, West Chairman and CEO Dwight Opperman was present along with a number of West employees. A Wisconsin lawyer retained by West marshaled the company's arguments against the twin proposals. In all, thirty or so individuals testified at the hearing; more than seventy were in attendance. (The court had also invited written comments and received a large quantity of them. $)^{14}$

8. See Leiter, supra note 3, at 1. A full archive of LAW-LIB postings from that period is available at http://lawlibrary.ucdavis.edu/LAWLIB/lawlib.html.

9. Around this time, in a speech to company employees on an initiative by the U.S. Justice Department aimed at loosening West's exclusive hold over publication of federal court decisions, West President Vance Opperman proclaimed dramatically: "We will win this battle. . . If they take us on, they're taking on a handful." Tom Hamburger \& Sharon Schmickle, High Stakes and Hot Competition; In Face of Change, West Publishing Fights to Maintain Its Lead in Legal Publishing, StAR Trib. (Minneapolis, Minn.), Mar. 6, 1995, at IA.

10. West's resources included its own employees, a fair number of whom were members of the Wisconsin Bar. All graduates of Wisconsin's two law schools employed by West in customer service or editorial positions were, by virtue of Wisconsin's diploma privilege, Wisconsin lawyers.

11. Cary Segall, Lawyers Oppose Database Plan, Survey Indicates, WIS. ST. J. (Madison, Wis.), Jan. 27, 1995, at 8B. See also Donna M. Bergsgaard \& William H. Lindberg, A Dissenting View, in TASK Force on Citation Formats, Am. Ass'N OF Law Libraries, Final Report (1995), reprinted in 87 LAW LiBR. J. 580, 609 (1995) [hereinafter AALL TASK FORCE FinAL REPORT] ("While slightly more than half of the [Wisconsin] bar now use computers to some extent in legal research, the remaining $45 \%$ are using printed sources exclusively.").

12. Donna M. Bergsgaard \& Andrew R. Desmond, Keep Government Out of the Citation Business, 79 Judicature 61, 61 n.1 (1995).

13. Berring's participation was challenged by CD-ROM publisher Alan Sugarman who wrote urging the court not to allow his testimony unless Berring acknowledged his business ties to the company. Berring did acknowledge that West paid his travel expenses but emphasized that his testimony would reflect his own views. Pat Schneider, Law Book Giant Uses Big Guns in Turf War, Capital Times (Madison, Wis.), Mar. 21, 1995, at 3A.

14. The author was not present, but was one of many submitting written statements. This account of the hearing is drawn from two contemporary newspaper accounts. Id.; John J. Oslund, Badgering the Legal System; Proposed Change to Citation Format in Wisconsin Draws Protests from West, STAR TRIB. (Minneapolis, Minn.), Mar. 22, 1995, at 1D. 
I5 Conceding that not all the state's lawyers were comfortable with the consequences of technological change, the president of the Wisconsin Bar called upon the court to perform an "act of leadership and vision." Those representing small law publishers argued the benefits of increased competition. Berring's testimony urged the court to proceed with caution. "Your current system is powerful," he said. "There is no need to sacrifice it."15

I6 Following two months of deliberation, the Wisconsin Supreme Court took Berring's advice. In May 1995, it announced that decision on the matter would be deferred for a year and a half. ${ }^{16}$ Ultimately, the court delayed formal action until 1999 when it adopted what the implementing rule termed "public domain citation," effective at the beginning of $2000 .{ }^{17}$ Even then, the rule compromised on that point; it did not fully substitute the new citation system for volume and page numbers. By the rule's terms, tables of cases in briefs submitted to Wisconsin appellate courts were still required to cite decisions to both the Wisconsin Reports and the North Western Reporter in parallel with citations using the new format. ${ }^{18}$ More importantly, the second element of the bar proposal, establishment of a public digital archive of state case law, remained and still remains on the shelf. To this day, the Wisconsin Supreme Court's rules designate "Wisconsin Reports as published by Lawyers Cooperative Publishing and the Wisconsin Reporter edition of the North Western Reporter published by West Group as official publications of the opinions, rules, and orders of the court of appeals and the supreme court. ..." Although there is an archive of decisions at the Wisconsin Court System

15. This summary of Berring's testimony appears in Oslund, supra note 14. His views on the underlying issues had already been widely disseminated. In October 1994, he posted on the Internet a draft of the article that subsequently appeared as Robert C. Berring, On Not Throwing Out the Baby: Planning the Future of Legal Information, 83 CAL. L. Rev. 615 (1995), inviting comments via the LAW-LIB electronic discussion list. He also contributed a condensed version to the January 1995 issue of Legal Information Alert devoted to the "cite fights." See Bob Berring, Disadvantages, 14 LeGal. INFo. ALERT, Jan. 1995, at 5 (essay advocating retention of traditional citation approach).

16. John J. Oslund, Wisconsin High Court Delays Decision on Case Citation Plan, STAR TRIB. (Minneapolis, Minn.), May 26, 1995, at 1D.

17. The court did use the intervening period to develop staff experience with paragraph numbering. Telephone interview with Marcia Koslov, Library Director, Los Angeles County Law Library, and Wisconsin State Law Librarian, 1974-2000 (Nov. 8, 2006). Paragraph numbers were first attached to Wisconsin Supreme Court decisions in January 1997, and Court of Appeals decisions in October 1999.

18. WIS. SuP. CT. R. 80.001, 80.02. Most other states adopting neutral citation have done the same. See infra TII 21-25.

19. WIS. SUP. CT. R. 80.01. The rule still speaks of Wisconsin Reports as a publication of Lawyers Cooperative Publishing even though that brand name was eliminated by Thomson following its acquisition of the West Publishing Company, discussed infra II 8. That acquisition brought both sets of "official reports" of Wisconsin decisions into the hands of a single publisher, Thomson West. The terms of the consent decree approving the merger permitted Wisconsin to seek another publisher for the Wisconsin Reports. United States v. Thomson Corp., 949 F. Supp. 907, 912 (D.D.C. 1996). It was not really in a position to do so since the Wisconsin Reports were not then and are not now produced under contract with the state.

The Wisconsin Rule does contemplate the possibility of a public agency publishing state case law, for it provides that should an authorized state agency do so "in a format approved by the supreme court" its publication would join the list of "official publications." WIS. SUP. CT. R. 80.01. Wisconsin's Revisor of Statutes Bureau has long been the "official publisher" of the Wisconsin statutes and administrative code. See Wis. State Legislature, About the Revisor of Statutes Bureau, http://www.legis.state.wi.us/rsb/about_rsb.htm (last visited Jan. 10, 2007). 
Web site that reaches back to 1995 , and decisions from 2000 forward carry full public domain citation information, each also bears the notation: "This opinion is subject to further editing and modification. The final version will appear in the bound volume of the official reports." ${ }^{20}$ This is not the archive of final decisions recommended by the Wisconsin Bar. ${ }^{21}$ Indeed, no state agency possesses electronic copies of Wisconsin decisions as published. ${ }^{22}$

\section{That Was More Than a Decade Ago}

97 The Wisconsin Bar report and ensuing debate took place more than a decade ago. In the years following, enormous change has occurred in the distribution of legal information. The neutral citation ${ }^{23}$ scheme urged on the Wisconsin Supreme Court was subsequently endorsed and refined by the American Association of Law Libraries (AALL) ${ }^{24}$ and the American Bar Association (ABA). ${ }^{25}$ It was, for a brief

20. See, e.g., Shaw v. Leatherberry, $2005 \mathrm{Wl} 163$, as it appears at the Wisconsin Court System site, http:// www.courts.state.wi.us/opinions/sopinion.htm. (Since the site does not enable retrieval by citation, the simplest way to access any specific decision is by means of a Google search using party names and citation.)

21. A critical element of the public archive recommendation of the Wisconsin Bar was that the court system possess a digital copy of the final "official" version of each decision, the standard against which all other versions could be measured. As the president of the Wisconsin Bar explained, "The text of the archival version would be authoritative in the event of variation in the published versions." Gary Sherman, A Simplified System of Citation, 79 JudiCaTure 60, 62 (1995). The Technology Resource Committee Report noted that "[b]ecause the opinion may be edited in the publishing process, the State does not possess a "final' copy of the opinion." WISCONSIN BAR REPORT, supra note 4, at http://www.law.cornell.edu/papers/wiscite/problems.html. The report's archive recommendation specified that "[t]he archive reflect any post issuance editorial changes." Id. at http://www.law.cornell .edu/papers/wiscite/proposal.html. Because the court's archive does not, the aim of the bar's recommendation has not been realized.

22. E-mail from Cornelia G. Clark, Clerk, Wisconsin Supreme Court and Wisconsin Court of Appeals, to author (Aug. 30, 2006) (on file with author).

23. Diverse terms have been used to characterize this approach to citation. The AALL TASK FORCE FINAL REPORT, supra note 11 , at 587, II 18, referred to "vendor and medium neutral citation." The Special Comm. on Citation Issues, Am. Bar Ass'n, Report and Recommendations 6, 111 (1996) [hereinafter ABA CITATION Issues REPORT], available at http://www.abanet.org/tech/trc/research/ citation/report.html, recommended a "universal citation system." This same terminology was employed in CONFERENCE OF CHIEF JUSTICES, REPORT OF THE COMMITTEE ON OPINIONS CITATION 11 (1999), available at http://ccj.ncsc.dni.us/finalrpt.pdf, and in the title of the AALL Universal Citation Guide. The Bluebook: A Uniform System of Citation 88, R. 10.3.3 (Columbia Law Review Ass'n et al. eds, 18th ed. 2005) [hereinafter THE BLUEBOOK] refers to "public domain" citation, while the Ass'N of Legal Writing Directors \& Darby Dickerson, ALWD Citation Manual 98, R. 12.16 (3d ed. 2006) [hereinafter ALWD CITATION MANUAL] identifies "neutral citation." "Format-neutral" is yet another option. Berring, supra note 15, at 630. Except as this article refers to specific actions or recommendations using different terminology, it adopts the practice of the ALWD Citation Manual and collapses "vendor and medium neutral citation" into "neutral citation."

24. The AALL Task Force on Citation Formats appointed by President Kay Todd in 1994 issued its report recommending a Wisconsin-like approach in March 1995. AALL TASK ForCE FINAL REPORT, supra note 11. That report was endorsed by the AALL executive board in July 1995. AALL Citation Formats Committee, supra note 1, at 9, $\mathbb{7}$ (citing Minutes of the AALL Executive Board, July 13, $14,18 \& 20,1995$, at 2107-08 (on file at AALL Headquarters, Chicago)).

25. The ABA appointed a Special Committee on Citation Issues in August 1995. It produced a report that was released in final form in May 1996. The report led in August to a House of Delegates resolution calling on the nation's courts to adopt neutral citation. Both report and resolution are available in ABA Citation Issues RePort, supra note 23. 
moment, pressed on the federal judiciary by the Antitrust Division of the U.S. Justice Department. ${ }^{26}$ More importantly, neutral citation has been implemented in some form by more than a dozen states ${ }^{27}$ without the dire consequences that the late West Publishing Company forecast.

I8 That opposing force, the West Publishing Company, has been absorbed by the Thomson Corporation, previously an opponent of proprietary citation. During the turbulent period running through the Wisconsin Supreme Court hearing and decision to defer, West presented itself as a true partner with the nation's courts and legislatures, serving the public interest in the timely and accurate dissemination of law-being uniquely suited for this role by virtue of the company's long history and U.S. ownership. ${ }^{28}$ In late 1994 , commenting on the sale of LexisNexis to Reed Elsevier and the acquisition of Prentice-Hall Law \& Business by Wolters Kluwer, West's president had proclaimed, "This American-owned company is not for sale." 29 Less than a year later, three months after the Wisconsin Supreme Court announced its decision to defer on neutral citation, West's CEO announced that the company was pursuing a range of options, including sale..$^{30}$ In February 1996, the company's purchase by the Thomson Corporation for $\$ 3.4$ billion was announced and, roughly a year later, the transaction's final legal hurdle was cleared with court approval of a consent decree resolving antitrust claims. ${ }^{31}$

II9 While the Wisconsin Bar report spoke of possible public access to state legal information via the Internet, ${ }^{32}$ at the time that had to be imagined. Some

26. See Comments of the Department of Justice Before the Committee on Automation and Technology, Judicial Conference of the U.S. (Mar. 14, 1997), available at http://www.hyperlaw.com/jccite/346 .txt.

27. For the most accurate and up-to-date inventory, see The BlueBooK, supra note 23, at 198-239 tbl. T1. A full list includes Louisiana, Maine, Mississippi, Montana, New Mexico, North Dakota, Ohio, Oklahoma, South Dakota, Utah, Vermont (for some reason overlooked by The Bluebook), Wisconsin, and Wyoming.

Since neither the policy adopted by the Colorado Supreme Court in 1994-95 authorizing publishers to include paragraph numbers (an invitation none accepted), Memo from Mac V. Danford, Clerk of Court, Supreme Court of Colo., to Publishers (May 25, 1995), available at http://www.aallnet. org/committee/citation/rules_co.html, nor the order filed by the Washington Supreme Court in 2004 directing the publisher of that state's official reports to add paragraph numbers, In re Paragraph Numbering for Opinions Published in the Wash. Reps., Order No. 25700-B-447 (Nov. 8, 2004), available at http://www.courts.wa.gov/appellate_trial_courts/supreme/?fa=atc_supreme.paraOrder [hereinafter Wash. Paragraph Numbering Order], approaches the aims set out in the Wisconsin Bar study, those two states are not included in the above list. Arizona courts have been numbering paragraphs since 1997, but since the state supreme court declined to adopt a neutral case designation system and since Arizona pinpoint citations must continue to employ page numbers in parallel with paragraph numbers, Arizona is also excluded from the list. ARIz. R. Crv. APP. P. 13(a)(6).

28. During the citation debates, West representatives repeatedly referred to Thomson Legal Publishing and Lawyers Co-op as "foreign-owned." See, e.g., Bergsgaard \& Lindberg, supra note 11, at 611 n.16.

29. Daniel B. Kennedy, A Strategic Fit for Foreign Publishers, A.B.A. J., Jan. 1995, at 32, 32 (quoting Vance Opperman).

30. John J. Oslund, West Publishing Looks at Options, Including Sale, STAR TriB. (Minneapolis, Minn.), Aug. 30, 1995, at 1D.

31. United States v. Thomson Corp., No. 96-1415, 1997 U.S. Dist. LEXIS 2790 (D.D.C. Mar. 7, 1997).

32. WISCONSIN BAR REPORT, supra note 4, available at http://www.law.cornell.edu/papers/wiscite/ backgrnd.html. 
courts, including the Wisconsin Supreme Court, were still transmitting their opinions to publishers and online systems in hard copy. Today, no state judicial branch lacks a Web site. ${ }^{33}$ Most disseminate decisions on the day of release-to the legal profession, press, and broader public. Production and distribution of the printed law reports from which conventional case citations are derived have been in steady decline since the early 1990s. ${ }^{34}$ In 1995, a majority of lawyers and judges may well have relied on books for case law research, as West asserted. That is not today's reality. ${ }^{35}$

II 10 In view of these dramatic changes one might imagine that the twin reforms recommended by the Wisconsin Bar, neutral citation together with a public digital archive of decisions, would be widely implemented across the United States. The environment has changed so radically that the question for a jurisdiction's high court has shifted from "Why undertake such novel measures?" to "Why shouldn't the court's Web site be used in this way?" This article explores the factors that came together in the right way and at the right time in the few American jurisdictions that have, in fact, put those recommendations to work, as well as several factors that may explain why those states still stand as fairly lonely examples.

\section{Implementing the Wisconsin Proposals}

\section{Two State Courts That Moved Quickly Ahead}

\section{North Dakota}

I11 Ted Smith, law librarian of the North Dakota Supreme Court, followed the citation debate with interest. In September 1995, he prepared a memorandum on "Vendor/Medium Citation Form" for the state's chief justice, Gerald W. VandeWalle. ${ }^{36}$ With that memorandum, he also sent the AALL Task Force Report, the Louisiana Supreme Court's 1993 order establishing an earlier version of neutral citation, and notice of an upcoming hearing called by the South Dakota Supreme Court to consider a petition from the bar of that state seeking adoption of neutral citation in the format recommended by AALL. ${ }^{37}$ Both Smith and Chief Justice VandeWalle were aware that the South Dakota Bar's petition was prompted

33. For a comprehensive list of state court Web sites, see Nat'l Ctr. for State Courts, State Court Web Sites, http://www.ncsconline.org/D_KIS/info_court_web_sites.html (last visited Jan. 10, 2007).

34. See Tim Fuller, "The Most Accurate and Useful Law Books Possible," Wash. Terr., Wash., Wn.2d, and Wn. App.-Milestones of Official Case Reporting in Washington, WASH. ST. BAR NEws, Nov. 2005, at 22, 27, available at http://www.wsba.org/media/publications/barnews/fuller-nov05.htm; Telephone Interview with Brian Ervin, Reporter of Decisions, Illinois Supreme Court (Sept. 6, 2006).

35. Catherine Sanders Reach, David Whelan \& Molly Flood, Feasibility and Viability of the Digital Library in a Private Law Firm, 95 LAw LiBR. J. 369, 374, 2003 LAw LiBR. J. 26, II15.

36. Memorandum from Ted Smith, Law Librarian, North Dakota Supreme Court Law Library, to Gerald W. VandeWalle, Chief Justice, North Dakota Supreme Court (Sept. 19, 1995) (on file with author).

37. Id. 
by a CD-ROM initiative aimed at reducing the cost of legal research in that neighboring state. ${ }^{38}$

I12 Smith's memorandum went beyond describing the neutral citation concept; it expressed support, summarizing the strongest arguments for the change. Although Smith also presented the principal counterarguments, he characterized them as neither "persuasive" nor "insurmountable." The document concluded by observing that "West Publishing's recent announcement that they are investigating the possibility of selling out or going public may hasten the need or ... force the issue." 39

I13 A few months later, the ABA Special Committee on Citation Issues sent a copy of its draft report recommending neutral citation to all state chief justices. The covering memorandum from the committee chair specifically invited submissions from the judiciary. ${ }^{40}$ Shortly after its receipt, a "draft" statement supporting neutral citation was circulated among the justices of the North Dakota Supreme Court. ${ }^{41}$

I14 By chance, the sole academic on the ABA committee was a member of the North Dakota Law School faculty, Professor Patricia Fry. On April 2, at her request, the North Dakota Supreme Court justices met with Fry to discuss the committee's draft report. ${ }^{42}$ Following that meeting, the court formally adopted a statement supporting "the creation and use of simple, uniform case citations that are vendor- and medium-neutral" along with "[p]arallel citation to alternative sources." ${ }^{3}$ In January 1997, the court issued an order that "effective immediately, the Supreme Court of North Dakota will assign numbers to its

38. Dakota Disc, a bar-sponsored CD-ROM compilation of South Dakota law, including the South Dakota code (then being marketed on CD-ROM by Michie for $\$ 1500$ a year), appellate decisions, and pattern jury instructions, was ready for release in August 1994. However, because of West's copyright claim to the page numbers necessary for pinpoint cites to its National Reporter System, the product initially employed slip opinion pagination. Upon learning of the Wisconsin Bar's citation scheme, Dakota Disc's creator, Laurence Zastrow, began employing it on the CD-ROM. The bar petitioned the court to adopt neutral citation to legitimize use of citations drawn from this disk. The South Dakota Supreme Court did so following the October 1995 hearing referred to in the Memorandum from Ted Smith, supra note 36, with an order taking effect on January 1, 1996. West, which did not have a South Dakota CD-ROM product, agreed not to oppose the bar's request for paragraph numbering so long as the bar did not seek to displace the North Western Reporter as the "official" South Dakota reporter. E-mail from Laurence Zastrow to author (May 9, 2006) (on file with author). Consistent with that concession, all decisions at the Web site of the South Dakota Unified Court System carry a notice, similar to that at the Wisconsin site, that they are "subject to formal revision before official publication in the North Western Reporter." See S.D. Unified Court Sys., http://www.sdjudicial.com (last visited Jan. 10, 2007) (follow "Supreme Court" hyperlink; then follow "Opinions" hyperlink).

39. Memorandum from Ted Smith, supra note 36.

40. Memorandum from J.D. Fleming, Jr., Chair, ABA Special Committee on Citation Issues, to State Chief Justices (Jan. 26, 1996) (on file with author).

41. North Dakota Supreme Court Statement of Position Re: Uniform, Medium-Neutral Case Citations (discussion draft Feb. 28, 1996) (on file with author).

42. Telephone Interview with Patricia Fry, Edward W. Hinton Professor of Law, University of MissouriColumbia, and member of the North Dakota law faculty, 1983-2000 (June 14, 2006).

43. North Dakota Supreme Court Statement of Position on Uniform, Medium-Neutral Case Citations (Apr. 24, 1996) (on file with author). 
opinions as they are filed in the form ' $1997 \mathrm{ND} 1$,' with numbers assigned to paragraphs and, pending development of a rule, following generally the South Dakota model." 44 On March 5, 1997, it issued the promised rule that mandated use of the new system in any "brief, memorandum, or other document filed with any trial or appellate court" when citing decisions released on or after January $1,1997 . .^{45}$

II 15 In rough parallel with its implementation of neutral citation, the North Dakota Supreme Court launched a Web site (www.court.nd.us). The site went online in August 1996, offering decisions dating back to 1993. As soon as the court began attaching neutral citations to its decisions, the site distributed them in that form. It also associated the volume and page numbers in the North Western Reporter with each decision as soon as that print cite became available. By early 1997, the court's site enabled retrieval of individual decisions using either citation system. It also indexed the full collection by topic and opinion author, included brief abstracts with each decision, and offered full-text search. ${ }^{46}$ Recognized by AALL in September 1997 as the "best judicial site,"47 the North Dakota Web site has, ever since, set a standard for "best practices." In the years since, the site, created and maintained by Justice Dale Sandstrom of the North Dakota Supreme Court, ${ }^{48}$ has steadily expanded its content, functionality, and, consequently, its usefulness to the judges, other public officials, lawyers, and citizens of North Dakota. Its database of pre-1997 decisions has been systematically pushed back, in periodic increments. As of May 2006, the archive extended to the beginning of 1969 , covering more than thirty-seven years. ${ }^{49}$ Because the retrospective decision collection includes not only North Western Reporter citations for all pre-1997 decisions, but internal page-breaks as well, it is a full-service professional reference. Nothing at the site directs users to some other "official" source of the state's case law. ${ }^{50}$ The court's deci-

44. N.D. Supreme Court, Order in the Matter of Uniform, Medium-Neutral Case Citations (Jan. 15, 1997) (on file with author).

45. N.D. R. CT. 11.6 .

46. The history of the site can be traced in its "News" pages. See, e.g., N.D. Supreme Court News, Welcome to the N.D. Supreme Court Website (Nov. 19, 1996), http://www.court.state.nd.us/court/ news/new l.htm. In addition, the Internet Archive's Wayback Machine (www.archive.org) has pages from the site dating as early as January 19, 1998.

47. See N.D. Supreme Court News (Sept. 29, 1997), http://www.court.state.nd.us/court/news/new4.htm; Access to Elec. Legal Info. Comm., Am. Ass'n of Law Libraries, Good Overall Judicial Site, http:// www.aallnet.org/committee/aelic/bestjud.html (last visited Jan. 10, 2007).

48. By all accounts, credit for the original creation and continuous development of the site belongs to Justice Sandstrom. E-mail from Chief Justice Gerald VandeWalle, N.D. Supreme Court, to author (Apr. 4, 2006) (on file with author).

49. N.D. Supreme Court News, Another Step Backwards (May 8, 2006), http://www.court.state.nd.us/ court/news/step23.htm. The increments can be traced in successive "step backwards" pages. See, e.g., N.D. Supreme Court News, Another Step Backwards (Nov. 2000), http:/www.court.state.nd.us/court/ news/step3.htm (reporting the completion of the decisions from the 1990s).

50. This is in contrast to the Wisconsin and South Dakota court sites. See supra text accompanying note 20 ; note 38 . 
sions from the neutral citation era, now approaching a decade in length, can be retrieved with equal ease by any and all redistributors. As a consequence, even low cost and free law sites can offer post-1996 North Dakota decisions with full citation information. ${ }^{51}$ This is an open public resource in the contemporary sense. Since the site does not block indexing by Internet search engines, a search on Google for Sandberg v. American Family Ins. retrieves the decision (as does a search on that decision's neutral citation 2006 ND 198). The same search leads the researcher to the case docket that provides links to an audio file of the oral argument and the parties' briefs.

\section{Oklahoma}

II16 In January 1997, Chief Justice Yvonne Kauger of the Oklahoma Supreme Court hired that court's first MIS director. Kevin King, then still months away from his JD and an MBA in management information systems, came to this new position from the Oklahoma Court of Criminal Appeals where his technology know-how had been identified during a student internship. Like other courts that had not yet established one, the Oklahoma Supreme Court felt the need for a Web site. In addition, it faced other serious computer issues. The court was burdened by an ancient mainframe, running case tracking and administrative systems that were not Y2K compatible. It also lacked an effective network. King, with the support of the court's Technology Committee, chaired by Justice Joseph Watt (now chief justice), guided the court along a series of steps that produced the Oklahoma State Court Network (OSCN) (www.oscn.net), without dispute the most comprehensive court-based legal information site in the United States.

I117 At the time King was hired, Justices Kauger and Watt were already aware of the national reports on neutral citation and interested in implementing such a system. Through contact with Marcia Koslov, director of the Wisconsin State Law Library, ${ }^{52}$ King became a convert and developed the blueprint. Due to a fiscal crisis, it ended up being more ambitious than North Dakota's. Unpaid bills to the West Publishing Company run up by Oklahoma's county law libraries led all involved to see major gains in breaking the judiciary's dependence on West for access to citable versions of the state's own case law. Substantial independence required attention to past as well as future decisions. On King's urging, an initial citation rule limited to all decisions "promulgated after May 1, 1997" was amended before it took effect to accommodate application of decision and paragraph numbers to earlier decisions. Under the rule ultimately adopted, use of "the Supreme Court's official paragraph citation form" was "strongly encouraged for opinions promulgated prior to May 1, 1997" in addition to being required for subsequent ones. ${ }^{53}$ Fitting the new citations to past decisions required building a

51. For example, both VersusLaw and Findlaw have North Dakota decisions in citable form. That is not true of their collections of decisions from non-neutral citation states.

52. Koslov had served on the committee that produced the 1994 WISCONSIN BAR REPORT, supra note 4, and later on the AALL task force recommending neutral citation.

53. OKLA. SuP. CT. R. 1.200(e). 
full retrospective public archive. Work on a comprehensive database of Oklahoma decisions began in 1997.

I18 The court's decision-making process afforded little opportunity for opposition to mobilize. There was neither public notice nor a hearing on the plan. A week before the court issued its new citation rule, the executive committee of the Oklahoma Bar Association wrote the justices urging them to consider neutral citation, having no idea that the justices were well beyond the "consider" stage. ${ }^{54}$

I19 The Oklahoma legislature's solution to the county law library crisis was to centralize responsibility for meeting the libraries' legal information needs in the Oklahoma Supreme Court. The challenge was not simply financial; an initial assessment found key reference collections of more than half the seventy-seven county law libraries to be out of date. ${ }^{55}$ The court hired a law librarian to oversee both library consolidation and the legal database project, viewing the two as tightly connected. Over the next three and a half years new state law librarian Greg Lambert worked with King to construct the OSCN site. ${ }^{56}$

I20 By the time King and Lambert left the court's staff in July 2002, the site offered a database of Oklahoma decisions reaching back to $1890 \mathrm{OK} 1$, completely tagged with neutral citations. The collection encompassed not only all past decisions of the Oklahoma Supreme Court but those of the Oklahoma Court of Criminal Appeals (back to its first decision in 1908) and the Oklahoma Court of Civil Appeals (back to the first decision from that court appearing in West's Pacific Reporter, dated 1968). The OSCN database also included and still includes the Oklahoma court rules, the Oklahoma statutes fully compiled, the Oklahoma Attorney General decisions, and more. ${ }^{57}$ All these resources are searchable and linked in two directions. References in an opinion to a prior decision, to a rule, or to a statutory provision are linked to the cited authority. These links, being indexed, point the other way as well. When a document is retrieved, whether it is a decision of the Oklahoma Supreme Court, a rule of the court, or a statutory section, the document is accompanied by a table of other items in the OSCN collection that cite it. Listed citing references carry notations such as "Discussed" or "Discussed at length." Named the "citationizer," this feature furnishes a form of annotation for Oklahoma statutes and court rules. Researchers can submit citations to the underlying cite-checking engine individually or as a list. Indeed, they can submit full

54. This account is principally based on the following sources: Telephone Interview with Yvonne Kauger, Justice of the Okla. Supreme Court (May 5, 2006); Telephone Interview with Kevin King, former MIS director, Okla. Supreme Court (June 2, 2006); E-mail from Greg Lambert, Librarian, King \& Spalding LLP and former director, Okla. Supreme Court Library, to author (June 21, 2006). See also Brad Hillis, The Court Beat, INTERnet L. RESEARChER, May 1999, at 11.

55. Griff Palmer, Court's Research System Hailed, Daily OKLAhoman (Oklahoma City, Okla.), June 23, 1997, at 1.

56. The site's development can be traced from December 1998 forward, using the Internet Archive's Wayback Machine (www.archive.org).

57. See Okla. State Courts Network, The Electronic Law Library for Oklahoma, http://www.oscn.net/ applications/oscn/start.asp?viewType=LIBRARY (last visited Jan. 11, 2007). 
documents for citation extraction and checking. To this day the site offers a comprehensive and integrated collection of Oklahoma law. Decisions of the Oklahoma appellate courts, as well as briefs submitted to them, employ neutral citations when referring to both pre- and post- 1997 decisions. These can be obtained for earlier decisions either by working directly from the texts stored in the OSCN database or by employing the site's citationizer service to translate volume and page numbers into the corresponding neutral cites.

\section{Steps Setting These States Apart from Other Neutral Citation Adopters}

\section{Parallel Citation Rules That Do Not Require Access to Internal Page Numbers}

I21 The goal of neutral citation in the format recommended by the Wisconsin Bar, AALL, and ABA is a single form of reference that will allow a lawyer or judge using one medium to cite to a specific portion of an appellate decision in terms that will enable others relying on different media ("printed editions, CD-Rom, via the Internet, and . . . new and as yet undefined technologies") to locate the cited passage without having to resort to a conversion table. Attached to decisions while they are still in digital form, prior to public release, neutral citation elements follow decision texts into print editions and the full range of digital distribution channels. ${ }^{58}$ In electronic environments, retrieval by alternative citation systems is a straightforward function, rendering parallel references to multiple schemes superfluous. On the other hand, finding a decision in a set of printed volumes by its neutral citation alone is a clumsier process, unless aided by a table or similar device. For this reason, the ABA neutral citation resolution of 1996 included a transition provision: "Until electronic publications of case reports become generally available to and commonly relied upon by courts and lawyers in the jurisdiction, the court should strongly encourage parallel citations, in addition to the [neutral] primary citation ..., to commonly used printed case reports." 59 Critically, the example embedded in the resolution and the supporting committee report make it clear that this recommended parallel citation for a decision need include only its beginning page, and not any form of pinpoint reference beyond the neutral citation's paragraph number. ${ }^{60}$

\$22 Most jurisdictions adopting some form of neutral citation have not merely encouraged the use of parallel citation to print reports, they have required it, at

58. This is where the Wash. Paragraph Numbering Order, supra note 27, directing its publisher to attach paragraph numbers, misses the mark. Being inserted well after release and then initially in print, these paragraph numbers don't accompany the decisions as they are retrieved and added to the case law collections of FindLaw, VersusLaw, or even Westlaw. The paragraph numbers appearing in Washington decisions on Westlaw and in the Pacific Reporter are added by Thomson West and don't always correspond to the numbering in the "official reports" produced by LexisNexis. E-mail from Tim Fuller, Reporter of Decisions, Wash. Supreme Court, to author (Aug. 28, 2006) (on file with author).

59. Am. Bar Ass'n, Universal Citation Resolution (1996), available at http://www.abanet.org/tech/trc/ research/citation/resolution.html.

60. The example furnished in the resolution is "Smith v. Jones, $19965 \mathrm{Cir} 15, \mathbb{1} 18,22$ F.3d 955." Id. 
least in a brief's table of cases or in connection with the first reference to a case. ${ }^{61}$ Most, although unfortunately not all, have understood that a parallel pinpoint page citation is not only unnecessary but that requiring it compromises a core goal of neutral citation. Maine's citation rule demonstrates the result. According to its terms, a pinpoint citation should take the form: Smith v. Jones, 1997 ME 7, II 14, 685 A.2d $110,115 .^{62}$ To obtain the necessary pinpoint page number, one must have access either to the Thomson West Atlantic Reporter in hardcopy or to an electronic source that has obtained that pagination from Thomson. ${ }^{63}$ As a consequence, the rule is not truly medium or vendor neutral.

II23 While North Dakota and Oklahoma require parallel citations, neither mandates the use of parallel page numbers in pinpoint citations. ${ }^{64}$ The North Dakota Supreme Court underscores this aspect of its rule by consistently modeling the practice. $^{65}$

\section{Provision of Parallel Citation Information with All Decisions}

I[24 The ABA's recommendation of parallel citation to print reports was explicitly transitional, to be continued only until electronic case reports became widely available and generally relied upon. Two states appear to have concluded, quite sensibly, that that time has come. Mississippi's neutral citation rule does not require parallel references to the Thomson West regional reporter covering the state. ${ }^{66}$ Under the Wyoming order, parallel references to the Pacific Reporter are optional for cases decided after 2003. ${ }^{67}$

I25 So long as parallel case citations are required, full vendor and medium neutrality calls for addition of that information to the jurisdiction's case archive, once available. That simple editorial step places users of the public site and collections derived from it in parity with those working from print reports and their electronic

61. See, e.g., WIS. SuP. CT. R. 80.02(3)(b).

62. Me. Supreme Judicial Court, Order SJC-216 (Aug. 20, 1996), available at http://www.courts.state .me.us/opinions/supreme/citation.html. For an example of the court's adherence to this format, see Wood v. Bell, 2006 ME 98, II 12, 902 A.2d 843. The Arizona Supreme Court has made the same mistake in ArIz. R. CIV. APP. P. 13(a)(6). See supra note 27.

63. The Web site of the nonprofit Cleaves Law Library in Portland, Maine, adds the parallel case citation information to Maine decisions as it becomes available, but neither it nor the court site on which it depends include the internal page breaks within decisions necessary for a parallel pinpoint cite. See Cleaves Law Library, Maine Supreme Judicial Court Decisions, http://www.cleaves.org/slip.htm (last visited Jan. 11, 2007). The same is true of the low-fee VersusLaw collection of Maine decisions.

64. N.D. Sup. Ct. R. 11.6; OKLA. SUP. CT. R. 1.200(e)-(f).

65. See, e.g., Marchus v. Marchus, 2006 ND 81, पा1 6-7, 712 N.W.2d 636.

66. Miss. R. ApP. P. 28(e).

67. Wyo. Supreme Court, Order Adopting a Public Domain or Neutral-Format Citation (Oct. 2, 2000), available at http://www.abanet.org/tech/ltrc/research/citation/wyucorder.pdf [hereinafter Wyoming Order 2000]. The order distinguishes between the format required in documents filed with the court and the format the court will use in its own opinions. The court itself continues to provide parallel citations to the Pacific Reporter, and, as of late 2005, the court's pinpoint citations include the Thomson West pagination. Wyo. Supreme Court, Order Amending Citation Format (Aug. 19, 2005), http://www.courts.state.wy.us/LawLibrary/univ_cit_amend.pdf [hereinafter Wyoming Order 2005]. 
counterparts. While North Dakota and Oklahoma have done this, as have several other neutral citation adopters, a few, Maine and Utah to name two, have not. ${ }^{68}$

\section{Archive of Final Decisions Rather Than Slip Opinions "Subject to Revision"}

I26 Most state court Web sites, whether or not the jurisdictions have adopted neutral citation, do not offer fully revised, final, cite-checked, and copy-edited versions of decisions. Typical is the site of the New Hampshire Supreme Court which continues to hold and serve 1995 opinions, each prefaced by the warning:

NOTICE: These opinions are subject to motions for rehearing under Rule 22 as well as formal revision before publication in the New Hampshire Reports. Readers are requested to notify the Reporter, Supreme Court of New Hampshire, One Noble Drive, Concord, New Hampshire 03301, of any editorial errors in order that corrections may be made before the opinion goes to press. Errors may be reported by E-mail at the following address: reporter@ courts.state.nh.us.69

As previously noted, the sites of the South Dakota Supreme Court, an early adopter of neutral citation, and the Supreme Court of Wisconsin follow the same practice. ${ }^{70}$

I27 The degree of discrepancy between a court's slip opinions and the final, definitive versions is a function of the level of editorial attention, including cite- and quotation-checking, that the court's decisions receive before initial release. For that reason, the objective dimensions of this problem undoubtedly vary from jurisdiction to jurisdiction, even from court to court within a state. It is not so large a problem as to dissuade commercial online services from loading slip opinions from state Internet sites and adding citation information, including internal pagination, to them without ever making the effort to conform them in other respects to the versions appearing in the court-designated "official" reports. ${ }^{71}$ Yet even if the chance of substantive discrepancy is slight, the risk, underscored by warnings like that quoted above, undoubtedly deters reliance

68. See, e.g., Me. Judicial Branch, Supreme Court Opinions, http://www.courts.state.me.us/opinions/ supreme/index.html (last visited Jan. 11, 2007); Utah State Courts, Appellate Court Opinions, http:// www.utcourts.gov/opinions/index.htm (last visited Jan. 11, 2007). Demonstrating the ease with which this can be done, the Cleaves Law Library of Portland adds parallel citations alongside its links to decisions held at the Maine Judicial Branch site. See Cleaves Law Library, supra note 63.

69. New Hampshire Judicial Branch, 1995 Supreme Court Opinions, http://www.nh.gov/judiciary/ supreme/opinions/1995/index.htm (last visited Jan. 11, 2007).

70. The earliest decision at the South Dakota site, Erickson v. County of Brookings, 1996 SD 1, and all decisions thereafter carry a notice to this effect: "These opinions are subject to formal revision before official publication in the North Western Reporter." See S.D. Unified Judicial System, January 1996 Opinions, http://www.sdjudicial.com/index.asp?category=opinions\&nav=5311\&year=1996\&month $=1$ (last visited Jan. 11, 2007). By contrast, the opinions distributed on the state bar's Dakota Disc, incorporate all revisions. E-mail from Laurence Zastrow to author (May 11, 2006) (on file with author). See supra II 6 for the Wisconsin notice.

71. This conclusion rests on a comparison of the versions of individual decisions from several jurisdictions across a range of commercial sites. 
on otherwise complete and useful public case law collections. That is particularly unfortunate when the researcher turns instead to a commercial site that has stripped off the warning but not invested in the editorial effort necessary to catch post-release revisions, large or small.

I28 In addition, as the 1994 Wisconsin Bar report argued, there is an underlying issue of political philosophy, one it framed with the question: "Who owns the law?" So long as a state fails to secure and maintain copies of judicial opinions in their "final" and "correct" form with all privately copyrighted material filtered out, it has relinquished control over the dissemination of its law. Even where there is an officially sanctioned public domain version of a jurisdiction's law reports, so long as the resulting additions to public case law collections are in print alone, the substantial costs of digitizing that material or conforming digital slip opinions to it will, in the current environment, grant significant de facto control to the publisher chosen to produce those reports.

I29 While neither the North Dakota Supreme Court Web site nor the Oklahoma State Court Network site goes so far as to designate the decision texts it holds to be "official," more authoritative source. The judiciaries of both states continue to cooperate in the publication of their decisions in the Thomson West National Reporter System, but their public archives of case law are not subordinated to the versions ultimately appearing in those books. ${ }^{73}$ Furthermore, when decisions are revised after initial release, both states' court sites incorporate the revisions. Several other states follow this latter practice as well, including a few that, commendably, flag revisions when they occur. ${ }^{74}$ The dominant practice, however, is for a court to warn those using its Web site that the texts it offers are not the final versions and that those are to be found in a designated set of printed law reports.

72. By contrast, the Web-accessible version of the Utah Code (www.le.state.ut.us/ code/code.htm) proclaims itself "an official publication of the Utah State Legislature." The Utah Administrative Code Web site (www.rules.utah.gov/main) indicates that it "is an electronic publication, although a paper version is available from a private publisher." See generally Richard J. Matthews, The Smart Citizen's Search for State Law on the Web, AALL SPECTRUM, July 2006, at 21.

73. A 1980 order of the North Dakota Supreme Court, apparently adopted to comply with N.D. CENT. CODE $§ 27-02-24$ (2006), does designate North Dakota opinions published in the North Western Reporter following the cessation of the North Dakota Reports in 1953 to be "the official reports" of the court's decisions.

74. E.g., Me. Judicial Branch, http://www.courts.state.me.us/opinions/supreme/index.html (last visited Jan. 12, 2007) ("Although opinions posted on this site are public documents and may be utilized and cited in this form, they are subject to revision and correction. When a revision or correction is made, the new version of that opinion will be posted on this site. The date of revision or correction as well as the date of initial publication will be indicated.") Decisions posted at the site maintained by New York's Law Reporting Bureau (www.courts.state.ny.us/reporter/Decisions.htm) initially carry the notice "This opinion is uncorrected and subject to revision before publication in the Official Reports." After any revision, the altered text carries a different notice indicating the date of revision, such as: "As corrected through Wednesday, May 24, 2006." The New Mexico site (www.supremecourt .nm.org) separates slip decisions, still subject to revision, from its archival collection. 


\section{Significant Retrospective Case Law Collections, with Full Citation Information}

\$30 Case law accretes. One year's decisions do not, with rare exceptions, displace decisions rendered over the many years that came before. Anyone searching for, analyzing, and then citing authority relevant to a current matter must work with the old as well as the new. For this reason, the gains from implementing neutral citation and establishing a case archive can seem quite modest at the point of transition. Typically, the reforms operate prospectively, applying only to subsequent decisions. Prior decisions, lacking neutral citations, must be cited by volume and page number. Where those volume and page numbers must be drawn directly or indirectly from the proprietary National Reporter System, full vendor independence is not achieved. Of course, as a neutral citation system operates over time, fewer and fewer cited decisions will date from the proprietary print citation era.

I31 Like most states that have adopted neutral citation, North Dakota and Oklahoma had, years before, given up contracting for and supervising the production of their own law reports. For them the reform meant vendor as well as medium neutrality. Jurisdictions in this posture, a set that includes close to half the states plus all federal courts below the U.S. Supreme Court, have particular incentive to regain control over dissemination of their decisions in citable form. They also confront a distinct challenge in addressing legacy case law.

\$32 Oklahoma's solution to the problem, already described, was ambitious in the extreme-creation of a full retrospective case law database, complete with neutral citations. Under the Oklahoma neutral citation rule, pre-1997 decisions can be cited by year, case number, and, in the case of a pinpoint cite, paragraph number, together with a parallel print citation. Since the OSCN site furnishes the necessary parallel citation for each case and since pinpoint citations require only paragraph numbers, complete vendor independence is the result. That is true not only for those using the public site directly; this approach permits commercial redistributors to offer a fully citable Oklahoma case law collection without having to worry about copyright claims to pagination. ${ }^{75}$ Mississippi's neutral citation rule also contemplates retrospective application, ${ }^{76}$ although to date only 1996 decisions have been added to the Mississippi Supreme Court's site with the necessary paragraph numbers. ${ }^{77}$

II33 North Dakota's approach to the legacy case law problem did not involve changing how pre-1997 decisions could be cited. It instead took the form of furnishing free public access to earlier decisions as they appeared in the North Western Reporter, complete with the pagination information needed for pinpoint

75. A subscriber to VersusLaw (www.versuslaw.com), for example, has access to more than fifty years of Oklahoma decisions with all the citation information needed to refer to them in an Oklahoma proceeding.

76. See Miss. R. ApP. P. 28(e)(3)(iv).

77. See, e.g., Miss. Real Estate Comm'n v. Hennessee, 92-CC-01230-SCT (Miss. 1996), available at http://www.mssc.state.ms.us/Images/Opinions/Conv7097.pdf. 
cites. Already the online archive extends back to January 1969 and, thus, contains a majority of the decisions cited in contemporary North Dakota opinions and briefs. ${ }^{78}$ The court's ultimate target is $1950 .^{79}$ That will connect its digital archive, at that point representing more than fifty years of decisions, with the publicly published North Dakota Reports, which ran up to 1953.

I134 North Dakota falls within the Eighth Circuit where West's copyright claim to National Reporter System pagination was upheld by a U.S. district court decision ${ }^{80}$ not long before its supreme court embarked upon this program. Since Thomson West has not relinquished this claim, the inclusion of North Western Reporter star pagination in the court's retrospective collection ran a litigation risk that the South Dakota $\mathrm{Bar}^{81}$ and cautious commercial online services still avoid. ${ }^{82}$ Consequently, it hasn't had the ripple effect of Oklahoma's retrospective application of neutral citation; commercial publishers have not drawn from this archive of legacy decisions. On the other hand, any North Dakota lawyer, judge, or citizen wanting to cite to a 1969 state decision can draw the necessary information from the court's free site.

\section{Digital Decisions That Are Truly Medium Neutral and Not Print Replicas}

\35 Most court Web sites remain locked onto the image of a decision as a printed document. The all-to-common approach at judicial sites is to present opinions in files designed to replicate the print slip opinions formerly distributed by the court. Even courts that number paragraphs distribute decisions in a format that preserves specific pagination, assuring that each document will appear on a computer screen as though it were divided into pages and will print in the same way. This printbiased approach frustrates a variety of potential gains offered by digital media.

78. Approximately $75 \%$ of the North Dakota case citations in a sampling of August 2006 North Dakota Supreme Court decisions are to cases from the state's neutral citation period, with more than $90 \%$ to cases from the period covered by the current case database.

79. N.D. Courts, ANNuAl RePORT 5 (2004), available at http://www.court.state.nd.us/court/news/ annualreport2004/2004Annual.pdf.

80. Oasis Publ'g Co. v. West Publ'g Co., 924 F. Supp. 918 (D. Minn. 1996).

81. Dakota Disc's collection of South Dakota Supreme Court decisions includes star pagination to the South Dakota Reports for decisions during the period of its publication (1890-1976), but not to the North Western Reporter for those it alone published in the twenty years prior to the South Dakota Supreme Court's implementation of neutral citation. See discussion supra note 38 for more about Dakota Disc.

82. Compare, for example, the version of Hummel v. Mid Dakota Clinic, P.C., 526 N.W.2d 704 (N.D. 1995) at the North Dakota Supreme Court site (www.court.state.nd.us/court/opinions/940218.htm) with that on VersusLaw (www.versuslaw.com).

The state's litigation risk is, of course, a smaller one. Not only is the Web site of the court producing the decisions against which the claim would be asserted a highly unattractive setting in which to test the continued viability of West Publ'g Co. v. Mead Data Cent., Inc., 799 F.2d 1219 (8th Cir. 1986), but it is generally accepted today - and may well have been foreseen when the North Dakota court launched this project-that states are not liable for money damages in cases of copyright infringement. See Chavez v. Arte Publico Press, 204 F.3d 601 (5th Cir. 2000) (holding that Congress lacked the power to abrogate state sovereign immunity in copyright infringement actions). 
I36 In contrast, the decisions available at the North Dakota and Oklahoma sites are structured to take advantage of the electronic environment, as well as the distributed architecture and functionality of the Web. The model for these sites is more online database than set of printed decisions. Freed by neutral citation from the need to replicate specific print features, they instead present decisions in files that include metadata or fields holding author, party names, or title, date, and citation. This allows decisions to be searched in ways now familiar to and expected by users of commercial systems. It also means that publishers drawing decisions from these sites need not extract them from the print-focused pdf format or employ software systems and editorial staff to infer important data elements from print layout.

I137 Those using the North Dakota Supreme Court and Oklahoma Supreme Court sites are able to retrieve decisions by opinion author or date because that information is distinctly tagged for each decision file. References within a decision to other documents held at the site are linked. Decision files are stored and structured in ways that facilitate linking, not only from within the site, but the architecture of both sites holds the potential for hyperlinked briefs and for online commentary with links into the site.

q138 Both sites have search engines that draw on these data features. The Oklahoma site's "citationizer" function automates a search for all cases citing a particular document. On the North Dakota site, a search using a case's neutral citation achieves the same result and finds all briefs citing the case. As that suggests, these are more than case law archives. Each decision is linked to a docket system, which in the case of the North Dakota site holds briefs, other associated documents, and streaming audio of the oral argument.

\$39 While neither of these sites rivals Westlaw or LexisNexis in functionality, they are easily navigated and searched. The structure placed in the documents they offer facilitates, rather than hinders, the work of commercial publishers. Finally, an Internet user need not be familiar with their contents or interface to retrieve a particular decision of interest. Unlike many court sites, these do not block indexing by external search engines. A Google search using party names or a citation will lead directly to the decision.

\section{Other Neutral Citation States Deserving Mention}

I40 While North Dakota and Oklahoma have taken all five steps described in the previous section, other neutral citation states have made significant strides in the same direction. Four, in particular, deserve mention. Two are states with a tie to the Oklahoma State Court Network. Between 1998 and 2002, OSCN not only built the Oklahoma case law database, but also loaded decisions from three other neutral citation states into the same system. ${ }^{83}$ With one exception, this interstate

83. Those collections are still accessible at Wyo. State Law Library, Index of Available Documents, http://wyomcases.courts.state.wy.us/applications/oscn/index.asp (last visited Jan. 12, 2007). 
activity ended in 2002. The exception is Wyoming, which adopted neutral citation in 2000, effective January 1, 2001. The Web site of the Wyoming Supreme Court links to a collection of Wyoming decisions that currently extends back to 1990 , explaining that it is maintained as a collaboration between the state law library and OSCN. ${ }^{84}$ Efforts to add the full text of older Wyoming decisions to the system continue ${ }^{85} \mathrm{As}$ is true with OSCN's retrospective Oklahoma decision collection, the earlier Wyoming decisions are presented with full neutral citation information and parallel Pacific Reporter citations. On the other hand, there is no provision in the original Wyoming neutral citation $\operatorname{order}^{86}$ or its subsequent amendment ${ }^{87}$ authorizing use of neutral citations for cases decided prior to 2001.

If41 New Mexico implemented neutral citation at the start of 1997. While its decisions were, like those from Wyoming, included in the original multistate OSCN database, New Mexico proceeded along its own independent course, disseminating decisions in electronic form in parallel with publication of the state's official reports. Both print and online publication are the responsibility of the state's Compilation Commission, a public body headed by the chief justice of the New Mexico Supreme Court. ${ }^{88}$ The New Mexico Supreme Court Law Library site (www.fscll.org) offers a case law database that reaches back to 1995. The two years of decisions it contains that pre-date neutral citation carry full pagination from the nonproprietary New Mexico Reports.

If42 The Montana Supreme Court implemented neutral citation, effective January 1, 1998. As in New Mexico, the state law library maintains Montana's online case law archive. A scanning project has pushed the library's collection of earlier decisions (and briefs) as far back as January 1980. However, all pre-1998 decisions are provided in slip form without any citation information. The publisher of the state's official reports, a local firm ${ }^{89}$ offers state primary law on CD-ROM and also sells a Montana Green Book that "provides parallel citations tables that cross reference Montana Reports, Pacific Reporter and public domain cites." Were

84. Wyo. Judicial Branch, Supreme Court Opinions, http://courts.state.wy.us/main.aspx (last visited Jan. 12, 2007).

85. Id.; E-mail from Kathy Carlson, Wyoming State Law Librarian, to author (Nov. 13, 2006) (on file with author).

86. Wyoming Order 2000, supra note 67.

87. Wyoming Order 2005, supra note 67. The amendment, applying to the Wyoming Supreme Court's own practice, calls for the resumption of parallel Pacific Reporter page numbers in pinpoint citations.

88. N.M. Supreme Court, http://www.supremecourt.nm.org (last visited Jan. 12, 2007) (explaining that the site is jointly maintained by the New Mexico Supreme Court and the New Mexico Compilation Commission). The commission's composition and authority are set out at N.M. STAT. $\S \S 12-1-1$ to -14 (2005 \& Supp. 2006).

89. Like New Mexico, Montana continues to oversee the publication of a set of official print law reports. Prior to the publisher's recent acquisition by LexisNexis, State Reporter of Helena was a purely local operation, as evidenced by the slogan on its site: "edited by Montanans for Montanans." State Reporter, http://www.statereporter.com (last visited Jan. 12, 2007). 
the state law library site to do much more, it would, no doubt, undercut the demand for those products. ${ }^{90}$

I43 Last on this list is Ohio, a relatively recent neutral citation adopter. A revised Manual of Citations issued by the state's reporter of decisions in 2002 sets out a scheme that, while diverging from the model recommended by the AALL and ABA, fully qualifies as neutral. ${ }^{91}$ Together with a court rule mandating paragraph numbering, ${ }^{92}$ Ohio's approach allows pinpoint citation without parallel page number references. The reporter's Web site (www.sconet.state. oh.us/ROD/default.asp) provides both full neutral citation information and, for each published case, volume and page number in the state reports. The site also has a retrospective case law collection that reaches back more than a decade; however, the decisions from the period before paragraph numbering began lack necessary citation information.

\section{Why Have More States Not Headed Down This Path? ${ }^{93}$ Cost, Confusion, Complexity?}

I144 After a short period, the principal arguments used by opponents of the Wisconsin Bar plan to persuade that state's supreme court to defer-cost, confusion, and technical complexity-were refuted by the experience of those jurisdictions that had proceeded to implement neutral citation and disseminate case law via the Internet. In January 1999, a committee report adopted by the Conference of Chief Justices ${ }^{94}$ addressed these concerns, point by point. While the conference was careful to avoid taking a position on neutral citation, the report reviewed issues and options that courts contemplating these reforms should consider. The document's approach was steadfastly practical and accommodated a wide range of court structures and practices. For example, it outlined several possible approaches to decision numbering that might be employed by courts divided into departments or divisions or in jurisdictions where decisions

90. Parallel citations are not furnished for cases from the neutral citation era, and the site warns users that the database is not the official archive nor is the library the official publisher of the decisions. State Law Library of Mont., Document Search Help, http://fnweb.isd.doa.state.mt.us/idmws/custom/SLL/ SLL_FN_Help.htm (follow "Instructions" hyperlink) (last visited Jan. 12, 2007).

91. See Reporter of Decisions, Ohio Supreme Court, Revisions to the Manual of Citations 3-6 (July 12, 2002), available at http://www.sconet.state.oh.us/ROD/pdf/Rev_Manual_Cit_02.pdf.

92. Ohio S. CT. ReP. OP. R. I(D).

93. This analysis focuses on the states, ignoring the federal courts. It does so for several reasons. First, in the excitement over neutral citation during the $1990 \mathrm{~s}$, disproportionate attention was paid to the federal courts. Second, since there are models of effective implementation at the state level, it appears more fruitful to inquire why some states have headed down this path, and others have not. Third, a look at the states may help frame issues and identify considerations that bear on the considerably more complicated federal judicial structure. The federal courts represent a larger and less coherently administered judicial structure than exists in many states. Moreover, the stakes, both public and private, in the status quo are much greater than in any state. In short, implementation of the Wisconsin Bar proposals in the federal courts poses unique challenges, albeit ones that a look at the states may help illuminate.

94. See CONFERENCE OF CHIEF JusticEs, supra note 23. 
remained subject to revision for a period following release. ${ }^{95}$ About the radical step of adding paragraph numbers to opinions, the report noted that this could be done either in the author's office or by "a central office when a final opinion is prepared for release." It also observed that "[s]imple software programs or macros capable of inserting paragraph numbers are readily available." ${ }^{\prime 96}$ Concerning cost, the justices stated flatly: "Those jurisdictions that are adding sequential opinion numbers or paragraph numbers report that no additional costs are associated with these activities." 97 The report also reviewed the undeniable cost elements entailed in establishing and maintaining "an official electronic version of a court's opinions." ${ }^{98}$ Those it identified were, in effect, the costs of maintaining a Web site, which, by 1999 , were already being borne by many court systems. The report concluded with a description of the Oklahoma experience, the minimal costs that state had incurred in creating a case law archive, and the very real benefits its chief justice attributed to the adoption of neutral citation..$^{99}$

\section{A Tangible Stake in the Status Quo}

II45 A court's consideration of direct digital dissemination of case law is inescapably influenced by the jurisdiction's stake in existing arrangements for publication and distribution of appellate decisions. Decades before their courts adopted neutral citation and began placing decisions on the Internet, North Dakota and Oklahoma abandoned contracting for the production of their own law reports. ${ }^{100}$ Both states had concluded that the expense of competing with West's National Reporter System was not warranted. Their courts cooperated closely with West in the prepublication editorial process, depended to some degree on the publisher for citeand quote-checking, and bought the resulting reports from the publisher. Having surrendered law report production to West, the two states had little or no control over the cost of this essential library resource for their trial and appellate courts or the prices lawyers, libraries, and others had to pay. To them, the later prospect of bringing competition into this market appeared quite attractive. The majority of the states that have implemented neutral citation fall in this category. ${ }^{101}$

I46 By contrast, in a few heavily populated and lawyered states, the market for print law reports remained large enough, and the quality and timeliness of the product competitive enough that publicly supervised law reports continued to be

95. Id. at 4-5.

96. Id. at 5 .

97. Id. at 6 .

98. Id. at $10-11$.

99. Id. at 11 .

100. The North Dakota Reports and Oklahoma Reports ceased publication in 1953. See ALWD CITATION MANUAL, supra note 23, at 387, 389.

101. In addition to North Dakota and Oklahoma, the states in this group include Louisiana, Maine, Mississippi, South Dakota, Utah, Wyoming. See id. at $374,375,379,393,396,400$. While there is still a set of reports denominated Wisconsin Reports, it is not produced under contract with the state. A few neutral citation states still contract for publication of state reports (Montana, New Mexico, Ohio, and Vermont). 
viable right through to the end of the twentieth century. In a handful or less, the contractual arrangements for production of these "official reports" still furnish sufficient value to publishers that they are prepared to offer discount prices and other forms of noncash return to the contracting states. So long as the "exclusive right" to produce and sell "official reports" can generate tangible fiscal relief for a state's judicial system, shifting to a pro-competitive scheme that affords all publishers equal access to citable, final decisions in digital format has limited appeal.

II47 With a shrinking market for print law reports, fewer and fewer states are able to extract significant benefits through an "official reports" contract. In the largest states, however, that remains possible. New York and California, ranking first and second among the states in number of practicing attorneys and size of judicial systems, ${ }^{102}$ provide the clearest examples. During the deliberations of the AALL Task Force in 1995, the California and New York officials responsible for producing their state's law reports spoke against neutral citation. The fact of their opposition is, in a sense, more important than the arguments they advanced; but both asserted that states that continued to maintain their own reports had no need for a new form of citation and would, therefore, not adopt it. Wrote California's State Reporter of Decisions Edward W. Jessen: "The proprietary citation problem is simply not significant in large states that have viable official reports with citations that are safely in the public domain (e.g., New York and California). Thus, those states most critical to the success of such a radical change in citation style will be the states least motivated to do so." 103 The professional association of public law reporters adopted a statement that stressed that citation in states producing their own reports was already "vendor neutral." 104 Frederick Muller, then New York's Reporter, emphasized the role of his office in the post-release editorial process: "My reporter's office corrects several thousand errors of a substantive nature each year, and makes many thousands of corrections of a stylistic nature. Thus, the final edited text which is officially reported may be significantly different than the unedited slip opinions initially released by the courts." 105

I48 As Jessen predicted, neither New York nor California has adopted neutral citation. Neither has created a public case law archive of the sort recommended by the Wisconsin Bar report. ${ }^{106}$ The reporters for both states are still able to put their

102. See Clara N. Carson, The Lawyer Statistical Report-The U.S. Legal Profession in 2000, at 239 tbl. IV.1 (2004); Nat'l Ctr. for State Courts, Court Statistics Project, State Court Structure Charts (2006), http://www.ncsconline.org/D_Research/Ct_Struct/Index.html.

103. Frederick A. Muller, Dissenting Opinion, in AALL TASK ForCe FInAL RePORT, supra note 11, at 624, 628 (quoting Letter from Edward W. Jessen, California State Reporter of Decisions, to AALL Task Force (Oct. 17, 1994)).

104. Id. at 625 .

105. Id. at 625-26.

106. The New York Law Reporting Bureau does use an interim citation system, but those interim cites drop away as soon as decisions acquire volume and page numbers. The "slip opinions" archived at the Bureau's Web site (www.nycourts.gov/reporter/Decisions.htm), dating from October 2003, include all revisions but lack citation information. That is available from a free database of the official versions furnished by New York's official publisher, Thomson West, through the Law Reporting Bureau site, but only under a very tight Web license. California's publisher, LexisNexis, provides access to a complete historic database of that state's precedential decisions, also under a very restrictive license. In addition, LexisNexis has stripped the decisions of all internal pagination. See Cal. Courts, Opinions: Official Publisher, http://www.courtinfo.ca.gov/opinions/continue.htm (last visited Jan. 14, 2007). 
official report contracts out for bids and secure substantial returns. The current contract between New York's Law Reporting Bureau and Thomson West calls for no payment to the publisher whatsoever. In return for the right to produce and sell New York's official reports in both print and electronic formats, the state receives all the computer equipment and software necessary for the reporter's office to do its work, together with technology support and staff training, ${ }^{107}$ ten thousand copies of the reporter's style manual and its supplement; ${ }^{108}$ more than a thousand subscriptions to the advance sheets, interim volumes, and final bound volumes for the state judiciary; free use of the online version of the state reports for all New York judges; ${ }^{109}$ and free copies of a CD-ROM edition for the Court of Appeals and Supreme Court Appellate Division. ${ }^{110}$

I49 The benefits flowing to California under its "no payment" contract with LexisNexis, are no less substantial, but take a quite different form. While California's contract yields fewer free sets of reports, it shifts an enormous amount of editorial work to the publisher. The staff of the New York Law Reporting Bureau performs all the editorial work on that state's official reports. California outsources those functions to its publisher, and under the state's official report contract, those services are furnished without charge. The publisher's personnel write headnotes and summaries, check quotes and citations, inspect decisions for compliance with California's policies concerning privacy of parties and witnesses and citation of unpublished decisions, and conform decisions to the state's style manual, all subject to review by the state reporter's office. ${ }^{11}$

I50 While smaller states cannot generate values of this magnitude through their "official report" contracts, some still achieve discounts for the judiciary on print reports and advance sheets, at least in relation to the prices charged the ever-dwindling number of private subscribers. A few have also secured access on favorable terms to an electronic edition. ${ }^{112}$ As Tim Fuller, reporter for Washington State,

107. Agreement between Gary D. Spivey, New York State Reporter, and West Publishing Co. $\$ 3$ (Oct. 25, 2005) (on file with author).

108. $\quad l d ., \S 6$.

109. Id., $\S \S 9(f)(2)-(5)$.

110. Id., $\S \S 11(\mathrm{~g})(2)-(3)$.

111. Publication Contract for the California Official Reports 11-12 (2003) ("Postfiling verification, correction, styling, and proofreading," "Summaries and head notes") (on file with author); E-mail from Edward Jessen, Reporter of Decisions, Supreme Court of California, to author (Nov. 15, 2006) (on file with author).

112. The current Illinois contract with Thomson West, for example, caps the price to the public for an advance sheet subscription at six times the rate for the state's bulk purchase of nine hundred subscriptions and the price to the public for a bound volume of the lllinois Reports at more than four times the state price. Contract between the Supreme Court of Illinois and West Group (Aug. 1, 2004) (on file with author). Unsurprisingly, Vermont receives a much smaller discount under its contract with LexisNexis. Contract for Editing, Printing, and Distributing the Advance Reports and Bound Volume of Volume 179 of the Vermont Supreme Court Reports (July 10, 2006) (on file with author). The New Hampshire contract yields up to 140 state law CD-ROMs for its judiciary. Contract for Editing, Printing and Binding Volumes 144, 145, 146, 147, 148, 149 and 150 of the New Hampshire Reports (Jan. 25, 2002) (on file with author). 
wrote in 2005 , in states other than the largest, the steady decline in the public sale of print reports combined with greater competition among online services offering the same content threatens this historic framework. ${ }^{113}$ So long as the approach remains viable, however, few state offices that contract for and oversee production of "official reports" are likely to favor creation of a public case law archive with neutral citation. When collapse does come, as inevitably it will in even the largest states, at least some of the states in this group should be reasonably positioned to move to the North Dakota-Oklahoma model. Having continued their own reports, they will be able to create retrospective case law archives without fear of a pagination-based copyright infringement claim. Moreover, states that have anticipated that day and exerted bargaining power while still possessing some may be able to secure at least some of the data such an archive will require without having to scan or key it from printed reports. ${ }^{114}$

I51 In most, if not all, states continuing to publish "official reports," the move to a digitally based approach will require legislative change. ${ }^{115}$ It will also require a shift in mind-set on the part of those state officials who are responsible for the current print-based dissemination process and the judges to whom they are responsible. The latter source of inertia is not limited to states that still produce their own law reports.

\section{Judicial Autonomy and Mind-Set}

I52 In 1997, prior to a hearing of the Automation Committee of the Judicial Conference of the United States focusing on neutral citation, the committee and the Administrative Office of the Courts surveyed federal judges and clerks regarding the $\mathrm{ABA}$ citation recommendation. The questionnaire presented the $\mathrm{ABA}$ neutral citation resolution, unaccompanied by even a summary of the committee's rationale. Critics asserted that the process was designed to draw the largely negative response it in fact received. Nonetheless, the grounds the responding judges gave for rejecting the neutral citation idea illustrate significant sources of institutional resistance. Given their place and role, most federal judges saw no need for change. Variations on "if it ain't broke don't fix it" were common. Served by ample print and online information resources, the judges themselves were insensitive to the issues of cost and inconvenience pressed by the lawyers, librarians, and small publishers who favored the reform. Few respondents had the slightest understanding of the potential benefits of attaching permanent citations to decisions at

113. Fuller, supra note 34, at 27.

114. Washington State has, for example, secured rights to and possession of data for case reports reaching back to the Washington territorial reports under a 2005 amendment to its official report contract. Office of Reporter of Decisions, State of Washington, Publishing Services Contract, PCH-2000-128, Amendment 3 (Apr. 22, 2005) (on file with author). The result is a free site with a state case law collection based on the printed official reports reaching back to 1854 (the first case in 1 Wash. Terr.). See Municipal Research \& Services Ctr. of Wash., http://www.mrsc.org (follow "Legal Resources" hyperlink, then follow "Court Decisions" hyperlink) (last visited Jan. 14, 2007).

115. See, e.g., GA. CODE ANN. §§ 50-18-20 to 50-18-36 (2006). 
the time of release. They worried greatly about the proposal's impact on those (like themselves) who still mostly used print law reports. Many focused on the burden of attaching sequence and paragraph numbers to decisions, unaware that jurisdictions that had already implemented neutral citation had found simple software solutions. Their comments generally took current institutional arrangements and computer systems as immutable and identified problems that implementation would pose for them. Proud and sensitive authors objected to the aesthetic blight and bureaucratic feeling that paragraph numbers would inflict on their opinions. When confronted with a bare ABA resolution and no leadership from within the federal judiciary supporting the reform, many bridled at being told by outsiders how to conduct a core function. ${ }^{116}$

I53 In North Dakota, Oklahoma, and other states that have in varying degrees implemented the Wisconsin Bar proposals, a number of factors have worked to overcome judicial attitudes like those reflected in the 1997 federal survey. To begin, all have proceeded with leadership from one or more members of the jurisdiction's highest court and an information expert working closely with them, the state law librarian or court MIS director. Judges are and ought to be busy being judges. To performance of that distinctive role, issues of citation or even case law access may seem peripheral at best. However, the highest courts of many states carry and discharge very real responsibilities over the jurisdiction's entire judicial system. Their judges are not only judges but system executives as well. Both North Dakota and Oklahoma have "unified judiciaries" in this form. Both states also have a "unified bar." While the ABA seemed an external body to numbers of the federal judges responding to the Administrative Office survey, the state bars of North Dakota and Oklahoma are important constituencies for the supreme courts of those states. Their justices needed little persuasion or reminding that effective distribution of state case law to lawyers practicing in small firms and remote communities was a matter deserving their attention.

I55 As Assistant U.S. Attorney General Joel Klien observed in testimony before the Judicial Conference Committee, while the burdens of citation reform fall on courts and judges, the anticipated benefits are largely realized by the bar and public and are widely dispersed. For reform to proceed, those in a position to make the change must be brought to see the potential long-term gains and to act in the public interest. ${ }^{117}$

116. For the text of the responses to the survey, see Hyperlaw, Comments to Judicial Conference re Citation Reform-March/April 1997, http://www.hyperlaw.com/jconf.htm (last visited Jan. 14, 2007). For a summary with comments, see HyperLaw Report--Judicial Conference Public Comments (Mar. 24, 1996), http://www.hyperlaw.com/jcmail.htm. See also Coleen M. Barger, The Uncertain Status of Citation Reform: An Update for the Undecided, 1 J. ApP. PraC. \& Process 59, 80-81 (1999).

117. Hearing before Automation Comm., Judicial Conference of the United States, re ABA Citation Proposal 11-12 (Apr. 3, 1997) (comments of Joel Klien, Acting Assistant Attorney General, U.S. Department of Justice, Antitrust Division), available at http://www.hyperlaw.com/jctrans.htm. 


\section{Scale and Complexity of Judicial Structure}

I55 North Dakota is one of the nation's least populous states. It ranks ahead of only Vermont and Wyoming in population, and Wyoming, Montana, and Alaska in population density. ${ }^{118}$ It has the fewest lawyers of the fifty states-1302 in active practice in $2005^{119}$ - and fewer than fifty state judges. ${ }^{120}$ The Supreme Court of North Dakota is the only standing appellate court. As previously noted, it holds major administrative responsibilities for the state's entire judicial system and works closely with a unified bar. The court's output of "reported" decisions is about two hundred per year.

II56 In jurisdictions with greater scale and institutional complexity, thousands of decisions, and an intermediate appellate court with multiple districts or departments, accomplishing what North Dakota has poses a larger challenge. The roster of neutral citation-adopting states looks more like North Dakota in these dimensions than, to move to the far extreme, California or New York. For instance, six out of thirteen fall in the bottom quintile of states ranked by population and number of lawyers, only three rank in the top half by those measures, and eight exceed the national median for lawyers practicing in firms of ten or fewer. ${ }^{121}$ Six are among the eleven states having no intermediate appellate court. ${ }^{122}$

I157 On the other hand, Oklahoma's example cautions against overemphasizing variables like these. That state's judicial system has more than two hundred judges and includes not only an intermediate appellate court for civil matters, but a separate court of criminal appeals. ${ }^{123}$ In both population and number of lawyers, Oklahoma stands close to the national median. ${ }^{124}$

I58 Most, if not all, state courts of last resort have ample formal authority to direct the jurisdiction's intermediate appellate court to implement a specific system of identifying individual decisions, number paragraphs, and use a specified format in citing authority. ${ }^{125}$ They also have rules of appellate procedure into

118. U.S. Census Bureau, State Rankings-Resident Population (July 2005), available at http://www .census.gov/statab/ranks/rank01.html; U.S. Census Bureau, Density Using Land Area (2000), available at http://www.census.gov/population/www/censusdata/density.html (follow "Population, Housing Units, Area, and Density for States: 2000" hyperlink).

119. Am. Bar Ass'n, National Lawyer Population by State (2006), available at http:/www.abanet.org/ marketresearch/2006_national\%20_lawyer_population_survey.pdf.

120. See Nat'l Ctr. for State Courts, supra note 102. Adding municipal judges, the total is approximately 125. Id.

121. See U.S. Census Bureau, State Rankings-Resident Population (2005), supra note 118; Clara N. Carson, supra note 102 (state-specific tables).

122. See Nat'l Ctr. for State Courts, supra note 102.

123. Id. Adding municipal judges, the total is more than six hundred. Id.

124. See U.S. Census Bureau, State Rankings-Resident Population (2005), supra note 120; Clara N. Carson, supra note 104, at 239 tbl. IV.1.

125. For an extreme exercise of such authority, consider the Illinois Supreme Court's administrative order that from 1994 to 2007 capped the number of precedential decisions each of the state's five District Appellate Courts could file each year and the length of each (including concurring and dissenting opinions). Ill. Sup. Ct. M.R. 10343 (June 27, 1994) (copy on file with author). Numerous state courts have manuals that dictate opinion and citation format. See, e.g., N.Y. STATE UNIFIED COURT SYS., NEW YoRK LAW REPORTS STYLE MANUAL (2002), available at http://www.courts.state.ny.us/reporter/New_Styman .htm; Mich. Courts, Michigan Uniform System of Crtation (Admin. Order 2006-3), available at http://courtofappeals.mijud.net/rules/documents/9MichiganUniformSystemOfCitation.pdf. 
which they could insert a requirement that all documents submitted in connection with appeals use neutral citations. ${ }^{126}$ On the other hand, exercising that authority in the face of palpable resistance on the part of the judges, clerks, and other staff who would, in the end, have to change their methods of work carries real costs. The more decentralized the system, the greater those costs can seem. If there is uncertainty about the aim or about the benefits to be gained from a change like this, inertia or token reform are the most likely results. ${ }^{127}$

\section{A Mistaken Belief That the Copyright Problem Has Been Solved}

I59 At the time of the Wisconsin Bar's recommendations, West Publishing Company was aggressively defending its market position with two closely connected copyright claims. Together they stood in the way of public and private initiatives to provide additional, lower cost alternatives to West's law reports and their electronic derivatives. The first claim, at which the phrase "vendor neutral citation" took direct aim, was West's assertion that the precise placement of page breaks within any decision published in the National Reporter System was protected by the company's compilation copyright in the volume in which the decision appeared. West conceded that the decision as released by a court was in the public domain, free of copyright. By this time it had also conceded, when pressed, that other publishers could, without the company's permission, designate full decisions by the volume and page number at which they appeared in a West compilation. But any inclusion of "star pagination," enabling users of a competing database, CD-ROM, or print source to derive "pinpoint" or "jump" cites to particular passages within a decision, brought the very real prospect of a copyright infringement suit. This startling copyright claim rested solidly on a decision West had secured from the Eighth Circuit in litigation over star pagination with LexisNexis a decade before. ${ }^{128}$

I60 The report of the Wisconsin Bar Technology Resource Committee expressed doubt about the continued viability of this claim, citing a 1993 opinion by the Wisconsin Attorney General. ${ }^{129}$ The committee report went on to note, however, that until there was a definitive ruling on the pagination issue, the threat

126. Some state rules of appellate procedure dictate citation format with great specificity. See, e.g., FLA. R. APP. P. 9,800.

127. Reportedly it was resistance from appellate court staff that led the Washington Supreme Court to place the burden of numbering paragraphs on the publisher of the state's official reports. In re Paragraph Numbering for Opinions Published in the Wash. Reps., Order No. 25700-B-447, supra note 27.

128. West Pub. Co. v. Mead Data Cent., Inc., 616 F. Supp. 1571 (D. Minn. 1985), aff'd, 799 F.2d 1219 (8th Cir. 1986).

129. 81 Wis. Ops. ATt'Y. GeN. 45 (1993). The opinion based this conclusion on the Supreme Court's holding in Feist Publ'ns v. Rural Tel. Service Co., 499 U.S. 340 (1991), and that decision's reliance on a law review article that rejected the pagination copyright claim, L. Ray Patterson \& Craig Joyce, Monopolizing the Law: The Scope of Copyright Protection for Law Reports and Statutory Compilations, 36 UCLA L. REv. 719, 735 (1989). 
of litigation would continue to deter new entrants.

\$61 While there are totally independent grounds for citation reform, there seems little doubt that much of the energy behind the drive for "vendor neutral" or "public domain" citation during the 1990s came from a desire to break through the barrier to competition posed by West's refusal to allow others to incorporate National Reporter System pagination.

I62 West had a second copyright claim it was ready to bring against any wouldbe CD-ROM publisher who built a case law database by scanning or keying court opinions as published in any of the National Reporter System series. Conceding that decisions in the form released by an authoring court were in the public domain, West asserted copyright in the editorial work performed by its employees as they reworked the original texts into the versions appearing in the National Reporter System-placing opinions in a consistent format, adding information, conforming, checking, and expanding citations. ${ }^{130}$ While not directly mentioned in the Wisconsin Bar recommendations, this proprietary claim was directly addressed by the report's call for a state-controlled digital archive of decisions in their final, revised, and "correct" form.

I63 Through a series of developments, culminating in a pair of 1998 Second Circuit decisions that rejected West's key copyright claims, ${ }^{131}$ the pressure for citation reform they generated diminished. Indeed, it would be possible for someone not exposed to the litigation risk they still pose to conclude, mistakenly, that this particular problem associated with print-based citation had been eliminated.

I64 During negotiations over the terms of the consent decree that cleared the way for Thomson's acquisition of West, West's agreement to grant star pagination licenses to others than LexisNexis was trumpeted by the U.S. Justice Department as a key concession. ${ }^{132}$ Under pressure from District Judge Paul Friedman, West's agreed-to licensing terms were repeatedly liberalized. As Judge Friedman explained,

charging money to small publishers for obtaining a license to use a pagination system to which any copyright claim seems questionable would impermissibly shift the costs of

130. For a complete statement of the pagination claim as applied to a CD-ROM publisher who planned to prepare a collection of Florida decisions drawn from West's reporter, see Oasis Publ'g. Co. v. West Publ'g. Co., 924 F. Supp. 918 (D. Minn. 1996). For a more complete description of the second type of claim, see Vito Petretti, Note, Matthew Bender \& Co. v. West Publishing Co.: The End of West's Legal Publishing Empire? 43 VILL. L. REV. 873, $904-09$ (1998). West had at least one other copyright infringement claim it was prepared to bring against anyone scanning full volumes of its reports. Resting on West's unquestioned copyright claim to the synopsis and headnotes prepared by its editors, this intermediate infringement argument proceeded as follows. Even if the final product of the competitor contained none of this copyright-protected editorial matter, the copying of it in the course of scanning constituted, West argued, actionable infringement. See West Publ'g Co. v. On Point Solutions, No. 1:93-CV-2071-MHS, 1994 U.S. Dist. LEXIS 20040 (N.D. Ga. Sept. 1, 1994).

131. Matthew Bender \& Co. v. West Publ'g Co., 158 F.3d 674 (2d Cir. 1998); Matthew Bender \& Co. v. West Publ'g Co., 158 F.3d 693 (2d Cir. 1998).

132. See John E. Morris, How West Was Won, AM. LaW., Sept. 1996, at 73. 
litigating the legal uncertainty of West's Copyright claim. The Court was reluctant to put its judicial imprimatur on West's profiting from the licensing of star pagination where the underlying copyright claim appeared so thin. ${ }^{133}$

\$65 The final decree deferred all license fees for small publishers (a category that included the likes of Hyperlaw and Oasis but not LexisNexis, MatthewBender, $\mathrm{CCH}$, or BNA) "until a decision on the merits by the United States Supreme Court ... with respect to West's copyright claims or December 31, 2000, whichever comes first." 34 Notwithstanding the subsequent Second Circuit decisions on which the Supreme Court denied certiorari, the condition set out in the decree, namely, the rendering of a final decision on the merits by the United States Supreme Court, has not occurred. In fact, Thomson took steps in late 1997 to reduce the likelihood of such a final decision when it settled with a CD-ROM publisher against whom it had prevailed on the pagination issue. While an appeal in that case was pending before the Eighth Circuit, an appeal that had the potential to set up a division among circuits that might have induced the Supreme Court to grant certiorari, Thomson offered to license star pagination to the publisher and share its costs of litigation. The offer was accepted. ${ }^{135}$

\$66 To date, Thomson West has not renounced its previously asserted copyright claims. ${ }^{136}$ Risk-averse publishers either license National Reporter System pagination or don't include it. ${ }^{137}$ Unquestionably, the issue of proprietary citation has a lower profile than it did ten years ago, but it has not vanished. Although the underlying copyright claims are widely viewed as unsupportable, they have, to date, been rejected by only one U.S. Circuit Court of Appeals and it over a dissent.

\section{Altered Market Conditions}

I67 CD-ROM technology was transforming the legal information marketplace during the mid-1990s. Law Office Information Systems (LOIS) began selling state-specific primary law disks in 1995 for $\$ 600$ per year. ${ }^{138}$ Michie had also begun selling state primary law collections in a number of states with comparable annual charges, preceded by an initial fee. ${ }^{139}$ While West and Lawyers Co-op had CD-ROM-based versions of their state law print offerings, in the absence of com-

133. United States v. Thomson Corp., No. 96-1415, 1997 U.S. Dist. LEXIS 1893, at *7 (D.D.C. Feb. 27, 1997).

134. In re United States v. Thomson Corp., No. 96-1415, 1997 U.S. Dist. LEXIS 2790, at *51 (D.D.C. Mar. 7, 1997). See United States v. Thomson Corp., 1997 U.S. Dist. LEXIS 1893, at *7-10.

135. See Laura Gatland, West Settles Copyright Suit, A.B.A. J., Oct. 1997, at 37; Thomas Scheffey, A Cagey Move? Conn. L. TriB., Aug. 11, 1997, at 1.

136. On the contrary, its licensing practices affirm them. The contract under which Thomson West publishes the Illinois Reports includes a provision paying the state $\$ 10,000$ for a license to include "pagination to the Illinois Official Reports for display in West Group's electronic reporter products." Contract between the Supreme Court of Illinois and West Group, supra note 112.

137. VersusLaw, for one, doesn't include it.

138. Kendall F. Svengalis, Legal Information Buyer's Guide \& Reference Manual 125 (1996).

139. Id. at 453 (Minnesota). 
petition these were priced at levels that protected print sales. West's Iowa Reporter CD-ROM was offered for an initial charge of $\$ 2500$ plus $\$ 40$ per month after the first year. Its Iowa Code Annotated carried a $\$ 1200$ initial fee plus charges of $\$ 55$ per month for updates. Both prices corresponded closely to those for the respective items in print. ${ }^{140}$ In states like Arkansas that LOIS had entered with a CD-ROM, West and Lawyers Co-op dropped their prices to compete. ${ }^{141}$ Subscriptions to print case reports had begun to decline, and used sets of official reports were becoming available at one-quarter the cost of a new set, or less. ${ }^{142}$

I68 For the majority of lawyers, Westlaw and LexisNexis offered more than they needed at prices they couldn't afford. Although the two systems employed different methods of charging for use, both operated in ways that made these services unattractive to lawyers making repeated use of a limited portion of the data, such as those working primarily with the cases and statutes of a single state. With no print products to protect, LexisNexis had introduced a program of fixed rate pricing for such users. The program, however, was limited to those practicing alone or in very small firms and priced in 1995 at $\$ 1560$ a year for a solo practitioner. (The rate increased according to the number of lawyers in a firm. ${ }^{143}$ )

I69 In short, at the time North Dakota and Oklahoma moved to open dissemination of their case law to greater competition there was solid evidence that potential competitors were poised to enter the market with CD-ROM publications and that their entry could bring significant reductions in legal research costs for court systems and lawyers.

If70 By 2000, much had changed. U.S. lawyers, especially those practicing in small firms, enjoyed a striking array of less costly research options. LOIS, by then Loislaw, had moved to the Internet and expanded to all fifty states. The price for use of a Loislaw state law collection was $\$ 948$ per year; the annual charge for use of its full national collection (the fifty states plus federal primary law), $\$ 2148 . .^{144}$ Loislaw was underpriced in some jurisdictions by small CD-ROM publishers like Oasis (Massachusetts Case Law on CD-ROM for $\$ 199$ per disk), ${ }^{145}$ Compass Data Systems (Missouri Legal Research Tools, $\$ 299$ per year), ${ }^{146}$ and Geronimo Development Corp. (Casefinder, a Virginia primary law CD-ROM, $\$ 389$ per year for the first copy with a heavy discount for each additional one). ${ }^{147}$ Offering a national case law library online was VersusLaw, only $\$ 83.40$ per year for a solo practitioner. ${ }^{148}$ Also by 2000 , Westlaw, following the lead of LexisNexis, had

140. Id. at $430-432$. West's Oklahoma Decisions carried an initial charge of $\$ 2750$. Id. at 486 .

141. Lawyers Co-op offered its Arkansas CaseBase CD-ROM for $\$ 995$ with subsequent update fees lower than those for the LOIS disk; West's cases and code disk equaled the LOIS price of $\$ 600$ per year. Id. at 399 .

142. Id. at 67.

143. Id.

144. Kendall F. Svengalis, Legal Information Buyer's Guide \& Reference Manual 105 (2001).

145. Id. at 411 (Massachusetts).

146. Id. at 420.

147. Id. at 461 .

148. Id. at 111 . 
introduced fixed-rate plans designed and priced for small firms. The monthly charge for a single state Westlaw plan ranged between $\$ 100$ and $\$ 165$ per month depending on the state (for firms with one to two lawyers). ${ }^{149}$ Finally, by 2000, nonprofit and advertising-supported Internet sites offering law without charge had arrived in a serious way.

9171 Jurisdictions that had done nothing to facilitate the proliferation of options through citation reform benefited from these market developments alongside those that had. Were Oklahoma and North Dakota better off because of the initiatives taken by their supreme courts? Without a doubt. Their judges, lawyers, and citizens had access to substantial and citable collections of case law totally without charge. In addition, users of a free site like Findlaw or a very low cost site like Versuslaw could work with decisions from these and other neutral citation states without having to access a Thomson West source or some derivative to extract essential citation information. In the case of North Dakota and Oklahoma, these decisions were in their final form. Because of the altered market conditions, however, these gains were less conspicuous than those that prompted the original calls for reform.

\section{Reduced Pressure for Change from the Organized Bar}

\$72 In the years since 2000, state bar organizations have become major players in the case law dissemination picture. However, rather than calling on state courts to follow the lead of North Dakota and Oklahoma, with resulting benefits for the broader public, they are now contracting with commercial providers for online services limited to their members. Reflecting the current research needs and expectations of practicing lawyers, these services include more than case law. They also provide access to federal as well as state materials and integration through a single interface and search engine.

\$73 Earlier, bar groups had been used by commercial providers as a marketing channel. LexisNexis offered its MVP flat-rate plan through bar associations; Loislaw gave discount pricing to members of cooperating bar associations. A more active role for state bars emerged following the acquisition of Anderson Publishing Company by LexisNexis. That transaction catalyzed a chain of developments that has brought "free" online legal research to lawyers in more than half the states. First, it prompted the Ohio State Bar Association to join with the small firm (Lawriter) that had previously produced Anderson's Ohio law CD-ROM to move that disk's content to the Internet. Lawriter's past contractual relationship with Anderson blocked direct competition, but it did not stand in the way of the company's creating and maintaining research services for bar organizations. The Ohio Bar Association took a minority interest in the company ${ }^{150}$ and, working together

149. Id. at 106 (e.g., North Dakota, South Dakota, and Montana, \$100; Colorado, Kansas, and Oklahoma, \$130; Arizona, California, lowa, New York, \$165).

150. See T. R. Halvorson \& Margi Heinen, Casemaker: Ohio Incubates Another Legal Information Service, LLRX.COM, Sept. 16, 2002, http://www.llrx.com/features/casemaker.htm. 
under the name "Casemaker," Lawriter and the Ohio Bar created a consortium framework that bar organizations in other states found attractive. Bar groups that join the consortium contract with Lawriter for the creation of a state collection to their specifications (at a price varying according to those specifications) and proceed to offer the service as a membership benefit. As of April 2006, the Casemaker consortium included twenty-four state associations. ${ }^{151}$

I74 Casemaker has been joined in this field by an online newcomer, Fastcase (www.fastcase.com), and also by LexisNexis. In two years, Fastcase has signed up seven state bars, four large voluntary bar associations or membership libraries, and several trial lawyer groups. ${ }^{152}$ Unlike Casemaker, Fastcase is also available to individuals and firms unaffiliated with participating organizations. It also offers a full fifty-state case law collection. Casemaker, which had been proceeding to build its case law collection participating state by participating state, announced in 2006 that it, too, would expand its database to include the primary law of all states by the end of the year. ${ }^{153}$ Finally, LexisNexis has created "free for all members" plans for the New Jersey and Pennsylvania bars. ${ }^{154}$

\$75 While these bar-sponsored arrangements have increased options for lawyers, they have, for that very reason, reduced the pressure for reform coming from the organized bar. When the issues of case law dissemination raised by the Wisconsin Bar in 1994 are addressed by a state's judicial branch, the benefits flow not only to lawyers but to the broader public. Rhetoric about "public access" notwithstanding, ${ }^{155}$ courts are far less likely to view effective and open distribution of their own case law as a serious issue without pressure from the bar. ${ }^{156}$

I76 Recent Virginia events furnish a measure of the shift in the bar/court dynamic. In 2002, a new chief justice of the Virginia Supreme Court, seeking to improve the quality of legal research coming from the state's solo and small firm lawyers, turned to the state bar. Under his urging, ultimately translated into

151. Kendall F. Svengalis, Legal Information Buyer's Guide \& Reference Manual 148 (2006).

152. E-mail from Philip Rosenthal, President, Fastcase, Inc., to author (Nov. 14, 2006) (on file with author). See generally Alan Cooper, Fastcase Awarded Contract by Virginia State Bar, VA. L. WKLY, Feb. 6, 2006.

153. Casemaker, What Does the Casemaker Web Library Contain? http://www.casemaker.us (last visited Jan. 14, 2007) ("Beginning in 2007, Casemaker will include libraries for all 50 states.").

154. Pennsylvania Bar Association members have free access to a set of LexisNexis materials under a program named "InCite." See PBA InCite, http://www.pabar.org/public/cobranded.asp (last visited Jan. 14, 2007). A comparable program created by LexisNexis for the New Jersey State Bar Association is called "NJ CiteLine." See NJSBA Membership Benefits, NJ CiteLine, http:/www.njsba.com/ membership_info/index.cfm?fuseaction=benefits\#66 (last visited Jan. 14, 2007).

155. On the home page of the Wisconsin Court System, Chief Justice Shirley Abrahamson tells the state's citizens: "The courts of our state belong not to the lawyers and the judges, but to you-the public." Wis. Court Sys., From the Chief Justice, http://www.wicourts.gov (last visited Jan. 14, 2007).

156. Pressure from the state bar led South Dakota to become one of the first states to adopt neutral citation. The resulting success of the bar's Dakota Disc, available at a very reasonable charge, currently $\$ 500$ per year, to subscribing members (but not to nonlawyers), is one plausible explanation of the difference between the sites of the South Dakota and North Dakota supreme courts. E-mail from Laurence Zastrow, supra note 38 . 
a court rule adopted in June 2005, effective July 13, 2005,,$^{157}$ the Virginia State Bar entered into a three-year contract with Fastcase. ${ }^{158}$ Fastcase is now available to all members, paid out of dues. This occurred without the bar asking for or the Virginia Supreme Court contemplating any change in the way the state's decisions are disseminated or cited.

\section{Lack of Continuing Attention by Librarians and Other Information Professionals}

I77 A final factor slowing the pace of reform has been the dramatic decline in attention from law librarians. Individual librarians and their national association, AALL, led the early movement for neutral citation. Following the adoption of neutral citation in a number of states and the extension of the AALL's recommended neutral citation framework to statutes and administrative materials, the organization's interest moved on. With the problem of proprietary citation less easy to see, the blueprint drafted and elaborated, the benefits more diffuse than they were imagined to be during the turbulent days of 1994-96, issues of case law dissemination dropped off the professional agenda. Although AALL still has a Citation Formats Committee, the group has ceased to press for or monitor adoptions of case citation reform. ${ }^{159}$ Librarians and other scholars of legal information no longer write on the subject. The appearance of the ALWD Citation Manual in 2000 brought a short spurt of attention but only in the form of reviews of how the new manual treated neutral citation in comparison with The Bluebook. ${ }^{160}$ In the ongoing national debate over how to deal with "unpublished" decisions now that they are widely available online, citation and archiving have received minimal attention.

T78 Another committee of AALL recently completed a survey of state legal materials available on the Internet. ${ }^{161}$ Covering the full range of primary legal materials, statutes and administrative regulations as well as appellate decisions, the survey examined the "official status" of and "authentication" procedures, if any, available for publicly offered online law. The resulting report concludes with a call to action through advocacy and education. ${ }^{162}$ Because of the project's broad scope and the degree of attention the report pays to administrative codes and statutes, it is far from clear that this professional mobilization, should it materialize, will bring much fresh energy or attention to case law dissemination.

157. VA. SUP. CT. ORGan. AND Gov. R. 21.

158. See "Soft Launch" for Fastcase Service "Seamless," VA State Bar Says, VA. L. WkLY., Mar. 6, 2006.

159. The Citation Format Committee's list of neutral citation jurisdictions is seriously out-of-date and its Web site shows no sign of recent activity. See Am. Ass'n of Law Libraries, AALL Citation Formats Committee, http://www.aallnet.org/committee/citation (last visited Jan. 14, 2007) (indicating a last revision date of June 27, 2001).

160. See, e.g., Alex Glashausser, Citation and Representation, 55 VAND. L. Rev. 59, 89-90 (2002).

161. See generally Matthews, supra note 72 (describing AALL Authentication Survey administered as a joint effort by the Access to Electronic Legal Information Committee and AALL's Washington Affairs Office).

162. Id. at 32 


\section{The Recommendations of 1994 in the Light of Current Realities}

979 The range of case law sources available to lawyers, judges, and others needing to research the law is far greater today than it was a decade ago. The terms on which major segments of the market acquire access to case law are less likely to induce researchers to be cost-conscious in undertaking a particular task, to consider whether an alternative source might not be more economic. Commercial data collections furnish important functional gains through their integration of multiple primary law sources from a single jurisdiction and across multiple jurisdictions. At the same time it is far easier now than in 1994 to mix and match information sources, disparate sources accessed via the Internet (both free and subscriptionbased), online sources with those acquired on CD-ROM. Google and its competitors, portal sites, and contemporary operating systems all facilitate integration at the researcher's computer. One cumulative effect of these developments is that neither lawyers, whether practicing in private firms, large or small, or in the public sector, nor judges are as likely to see access to reasonably priced legal information to be the issue it was during the mid-1990s or to see citation reform and altered patterns of public case law dissemination as catalytic changes.

\$80 On the other hand, in a majority of states, the inefficiency of print-based citation norms is as real as it was a decade ago, if not more so. To begin, those doing primary research in printed law reports are a rapidly shrinking minority. ${ }^{163}$ In accordance with the consent decree allowing the Thomson-West merger, the asserted copyright in National Reporter System pagination is no longer used to block entry into the case law market, but the risk of litigation still affects the offerings and prices of Thomson's competitors. Even in jurisdictions with their own "official" reports, where pagination along with opinion text is explicitly placed in the public domain, the later acquisition and insertion of page breaks in decisions that have been online or on disk since their release carry substantial costs that a scheme of neutral citation would avoid. These costs are orders of magnitude greater than those involved in acquiring and adding parallel citation information. An online system like VersusLaw that does not add star pagination can offer case law at a lower price, but for jurisdictions without a neutral citation scheme its users must draw necessary pinpoint citation data from some other source. Immediate Internet access to electronic slip opinions accentuates the awkwardness of having to base case citation on volume and page numbers not available at the time decisions are released. The multiplication of sources quite literally multiplies the inefficiency in having to add citation information editorially to those slip opinions at a later date.

I81 So long as print case law sources were dominant, the notion of a virtual reference seemed or could be made to seem suspect. During the citation debates, West referred to neutral citation as "nowhere citation." In the current environment,

163. See Reach et al., supra note 35 , at 374 II 15. 
West's argument that a citation should indicate the actual source relied upon by the author can no longer be taken seriously as a ground for continued reliance on a volume and page number system. Lawyers and judges access, read, cite to, and quote from decisions and diverse other authorities they have drawn from digital sources even as they refer to them by volume and page number. When citations such as Powel v. Chaminade College Preparatory, Inc., 197 S.W.3d 576, 580 (Mo. 2006) or Alcoy v. Valley Nursing Homes, Inc., 272 Va. 37, 42-43 (2006) appear in an opinion or memorandum, it is far more likely than not that the references or quoted passages are based on the writer's review of the decisions in some version other than the printed law reports nominally referred to. ${ }^{164}$

II82 Now that decisions are available in digital format from public sites, commercial redistributors acquire them there. While LexisNexis, Westlaw, Loislaw, and some of the rest subsequently add page-break data to the original slip opinion texts, the thoroughness with which they also catch and incorporate post-release revisions in those texts is uneven and therefore, for users, uncertain. Uncertain quality has replaced cost as the greater issue. There is strong evidence that the economics of the industry prevent systematic steps to conform online texts to "official" print versions. So long as sets of print reports remain the ultimate standard, checking digital texts for conformity entails word-for-word proofreading. Whether or not lawyers and judges recognize the fact, that is not regularly done by digital publishers. While print reports remain the standard, and judges, reporters of decisions, and editors use delays inherent in the production of those reports to make post-release revisions, there exists an indeterminate risk of version discrepancy. The establishment of a digital archive of decisions in their final and official form at once reduces this risk and provides an efficient means of detecting differences when and if they arise; with authoritative electronic versions both publishers and researchers can use document-comparison software to identify discrepancies.

I83 To conclude, the two interrelated reforms recommended by the Wisconsin Bar in 1994 remain no less desirable twelve years later. The problems they address, although less conspicuous, are by virtue of the dominance and diversity of digital case law sources and the decline of print of even greater dimension. Most U.S. jurisdictions now release decisions to the Web. More than a dozen states have demonstrated that a shift to neutral citation is neither costly nor a serious burden on lawyers and judges. A few have shown how this reform can be combined with an open archive of decisions in final form. Year by year, the difficulty of following their example declines. As suggested earlier, the question confronting other states has shifted from "Why?" to "Why not?" Why not adopt neutral citation? Why not invest the effort to conform the jurisdiction's accumulation of electronic slip decisions, which in many cases extends back more than a decade, to their final

164. For a critical discussion of the Bluebook's historic confusion on this point, see Christine Hurt, Network Effects and Legal Citation: How Antitrust Theory Predicts Who Will Build a Better Bluebook Mousetrap in the Age of Electronic Mice, 87 IowA L. REv. 1257, 1276 (2002). 
"official" versions? In today's environment, that pre-Internet, pre-Google agenda constitutes an embarrassingly modest step toward improving the efficient and accurate dissemination of case law. 